This is a post-peer-review, pre-copyedit version of an article published in Empirica. The final authenticated version is available online at: https://doi.org/10.1007/s10663-020-09475-5

\title{
The Dynamic Effects of Non-Performing Loans on Banks' Cost of Capital and Lending Supply in the Eurozone*
}

\author{
Gabriella Chiesa $^{\S}$
}

\author{
José Manuel Mansilla-Fernández ${ }^{\dagger}$
}

\author{
December 24, 2019
}

\begin{abstract}
This paper analyses the transmission channel from non-performing loans (NPLs) to the cost of capital, credit provision and liquidity creation in the banks of the Eurozone. The empirical results suggest that holdings of non-performing loans increase both the long- and short-term cost of capital for banks. Moreover, the less capitalized the bank, the greater the reduction in credit provision and liquidity creation due to the increased cost of capital. This phenomenon is found to be more economically significant for European periphery country banks than for core country banks. The identification of the transmission channel is robust to the Granger predictability test.
\end{abstract}

Keywords: Cost of capital, credit supply, liquidity creation, NPLs, sovereign debt crisis.

JEL Classification: G11 G21 G32 H63

\footnotetext{
*Acknowledgements: We would like to express our gratitude to Fritz Breuss (Editor-in-Chief) and an anonymous referee for his/her thorough review, comments and suggestions, which significantly contributed to improving the quality of this article. We are indebted to Isabel Abinzano, Giorgio Barba Navaretti, Massimiliano Barbi, Giacomo Calzolari, Santiago Carbó-Valverde, Pilar Corredor, Luigi Filippini, Paolo Manasse, Luis Muga, Alberto Franco Pozzolo, Francisco Rodríguez-Fernández, Massimo Spisni, and seminar participants at the Department of Economics and the Department of Management of the University of Bologna, and the Business Administration Department of the Public University of Navarre for their helpful feedback and suggestions. All remaining errors are our own.

$\S$ Department of Economics, University of Bologna, Piazza Scaravilli 2, 40126 Bologna. Italy. E-mail: gabriella.chiesa@unibo.it

$\dagger$ Business Administration Department and Institute for Advanced Research in Business and Economics (INARBE), Public University of Navarre, Arrosadia Campus, 31006 Pamplona. Spain. E-mail: josemanuel.mansilla@unavarra.es
} 


\section{Introduction}

A key legacy of the 2008 economic crisis was the accumulation of non-performing loans (NPLs) in the Eurozone banking industry. Impaired loans grew at a steeper rate for Eurozone periphery country banks than for core country banks. Let us note that NPLs can be treated as observable information, since most European banks release their balance sheets on a regular basis. Bank equity investors might well cast doubts on the viability of the bank's business model, and on its future profitability and assets values. Moreover, NPLs are "impaired loans" and the possibility of an impaired loan eventually performing depends on the state of the economy, which constitutes aggregate (undiversifiable) risk (Accornero et al. 2017; Ghosh 2017; Pinto and Ng Picoto 2018). The fact that investors will demand relatively higher returns on equity investment in banks holding NPLs as a compensation for undiversifiable risk implies that banks' cost of capital increases with the volume of NPLs, - as illustrated in Figure 1.

\section{[Insert Figure 1 here]}

Bank capital serves as a buffer to absorb possible bank losses and avoid actual bankruptcy and / or restructuring processes. Indeed, a bank can control its default probability by limiting risktaking, e.g., by restricting lending and liquidity creation, and/or by increasing capital via equity issuance (Calomiris and Jaremski 2016); its choice will depend on the cost to raise capital.

This paper contributes to the existing literature by analysing the transmission channel from NPL holdings to the cost of capital, credit and liquidity creation in the banks of the Eurozone both in the long and the short term. Specifically, we examine whether NPLs drive equity investors' return requirements and thereby bank's cost of capital. We also analyse whether the cost of capital impacts negatively on credit expansion and liquidity creation, and if these effects are exacerbated by shortage of bank capital.

For our empirical analysis, we rely on a single dataset that covers the universe of Eurozone listed banks from Bureau van Dijk's Bankscope and Orbis Bank Focus, and market information 
from Thomson Reuters Datastream, covering 225 listed banks for the period 2002Q1-2016Q4. We employ the NPL ratio to measure the weight of impaired loans over total loans at the bank level. Importantly, the cost of capital is measured as the market's required return on bank equity; a linear combination of the yield on the 10-year Bund, the bank's Beta CAPM and the expected risk premium (ERP hereafter). Following previous studies, we measure lending supply as the proportion of credit to customers over a bank's total assets, whilst liquidity creation is computed following the methodology of Berger and Bouwman (2009) and Berger et al. (2016a). We test the transmission channel by estimating an autoregressive distribution lags (ADL hereafter) model which enables us to track the evolution of the impacts, period-byperiod, towards the steady-state.

Our empirical results suggest that NPLs increase the cost of capital for banks both in the long and the short-term, and that this impacts negatively on lending and liquidity creation. Whilst previous research has focused on the deleterious impact of NPLs on the book value of bank capital, this is, to the best of our knowledge, the first study to analyse the impact of NPLs on bank cost of capital, and, subsequently, the effects of the cost of capital on bank lending and liquidity creation.

Interestingly, we find that bank leverage enhances the sensitivity of lending and liquidity creation to the bank cost of capital, which means that the volume of lending by more highly capitalized banks is less affected by changes in investors' required return on bank equity holdings.

Taking into consideration that European periphery country banks accumulated comparatively more NPLs than European core country banks, we make separate estimations of the transmission channel for the two 'Europes', finding this phenomenon to be economically more significant for periphery country banks than for core country banks. Importantly, our findings confirm the view that the fragmentation of the Eurozone banking markets is a corollary 
of the NPL crisis. The results are robust to endogeneity tests; and the Granger causality test confirms the predictability relationship of the transmission channel under investigation.

The remainder of the paper proceeds as follows. Section 2 provides the background for the theoretical and empirical literature. Section 3 presents the data and the empirical framework; Section 4 describes the main results; and Section 5 concludes.

\section{Literature review}

This paper relates to the following three strands of the financial literature. The main question it raises is whether banks holding certain levels of NPLs might face higher capital costs over time. So far, previous literature has focused mainly on those determinants of NPLs due to bank under-capitalization and moral hazard issues (Caprio and Summers 1996; Berger and DeYoung 1997; Calomiris and Jaremski 2016), and aggregate risk (Louzis et al. 2012; Pinto and Picoto 2018). The role of bank equity capital has been considered as a cornerstone of the standard theory on banking regulation, since it decides the levels of lending a bank is able to supply (Caprio and Summers 1996; Calomiris and Jaremski 2016). The cost of equity capital is therefore an important determinant of a bank's lending activity. However, the cost of equity capital is an expected rate of return that cannot be directly observed from the market. Different measures have been used in the literature. The earliest strand of the literature used the realized return, i.e. return on equity (ROE) or Price/Earnings ratios, as a proxy for the expected return or cost of equity (Zimmer and McCauley 1991; Maccario et al. 2002). Other studies incorporate risk into the cost of equity by using the Capital Asset Pricing Model (CAPM), which is, in fact, the commonest method used by practitioners and financial advisers (Bruner, Robert F. et al. 9AD; Graham and Harvey 2001) and is also used by the FED following a review by the Fed's economists Barnes and Lopez (2006). King (2009) estimates the cost of equity capital over the period 1990-2009 for banks headquartered in six countries, namely, Canada, France, Germany, Japan, the United Kingdom and the United States. The estimates are based on CAPM and rely 
on the historical equity market risk premium treated as a constant. We approximate the cost of capital with the standard CAPM model. Our analysis complements King (2009) by focusing on the banks headquartered in all countries of the Euro area; by disentangling differences between core and periphery countries; and by revealing the key role played by the bank's stock of NPLs.

The literature shows growing attention to the repercussions of NPLs on bank lending, and ultimately on the real sector (Afonso et al. 2011; Bending et al. 2014; Balgova et al. 2016). This paper contributes by demonstrating that NPLs increase both long- and short-term capital costs for banks, and that this impacts negatively on lending and liquidity creation. Our results complement the static analysis performed in Chiesa and Mansilla-Fernández (2018). Whilst previous research has focused on the deleterious impact of NPLs on the book value of bank capital (Bogdanova et al. 2018; Fell et al. 2018), this study is, to the best of our knowledge, one of the first to analyse the persistent effect of NPLs on the bank cost of capital.

In a study closely related to our paper, Accornero et al. (2017) demonstrate that NPLs have a 'dynamic' transmission mechanism, which affects credit supply. They find that adjustments in the book value of capital (measured through the Asset Quality Review) have negative effects on bank lending, similar to those of negative shocks to bank capital buffers. In other words, NPL growth has negative effects on capital buffers, which might ultimately reduce credit supply (Van den Heuvel 2008; Berger et al. 2016a; Dagher et al. 2016). ${ }^{1}$ The results of the ADL estimation of the cost of capital show that higher capital costs reduce lending supply and liquidity creation both in the long and short term, and that these negative effects intensify with lower bank capitalization.

\footnotetext{
${ }^{1}$ Recent authors demonstrate that high levels of NPLs might deteriorate creditworthiness and reduce the demand for credit (Accornero et al. 2017; Balgova et al. 2016; Bending et al. 2014; Cuccinelli 2015).
} 
The purpose of this research is to analyse the dynamics of the relationship linking NPLscost of capital-lending and liquidity supply. Based on the reviewed literature, we propose the following three testable hypotheses:

Hypothesis 1 (Cost of capital): A positive impact of NPLs on bank cost of capital.

Hypothesis 2 (Credit supply): A negative impact of the cost of capital on credit supply, as this phenomenon intensifies with bank capital shortage.

Hypothesis 3 (Liquidity creation): A negative impact of the cost of capital on liquidity creation, as this phenomenon intensifies with bank capital shortage.

\section{Data and empirical framework}

\subsection{Data and sample selection}

We rely on bank balance sheet information provided by Bureau van Dijk's Bankscope and Orbis Bank Focus databases. The dataset comprises quarterly information for a sample of Eurozone banks for the period 2002 Q1 to 2016 Q4. ${ }^{2}$ We initially include consolidated balance sheets and income statements from commercial banks, savings banks, and credit unions operating in the Eurozone. All the banks included in our database display information for accounting years running from the $1^{\text {st }}$ of January to the $31^{\text {st }}$ of December. Since the abovementioned databases reveal the identities of the listed banks, we were able to extract all the institutions within this category. To avoid ambiguity and duplicate firm entries, banks were selected at the highest corporate level possible, usually as holding companies. The final sample includes 225 listed banks.

The rationale for the choice of sample period is that it begins before the financial crisis during which banks' lending and risk-taking was greatest (2002Q1-2007Q2), and also

\footnotetext{
2 The Eurozone Members included in our sample are Austria, Belgium, Cyprus, Estonia, Finland, France, Germany, Greece, Ireland, Italy, Latvia, Lithuania, Luxembourg, Malta, Netherlands, Portugal, Slovakia, Slovenia, and Spain.
} 
encompasses the banking and sovereign debt crises (2007Q3-2016Q4). The data are expressed in thousands of Euros and adjusted for inflation using the Harmonised Index of Consumer Prices. The final panel data sample is composed of 2,400 bank-year observations.

Since our focus is on the Eurozone market portfolio, we use the EURO STOXX Index to compute market returns. Information about equity prices at the bank- and market level, and sovereign credit risk is taken from Thomson Reuters Datastream.

For each listed bank, we obtained monthly times series of the EURO STOXX index from January 1990 to December 2016 in order to ensure a large enough window to estimate risk measures and expected returns. The data on sovereign credit default swaps (hereafter CDS) were obtained from the same database. The Thomson Reuters Datastream also provides information on sovereign CDS from 2008 onwards. GDP and unemployment rate data were drawn from the Eurostat database. Finally, the bank data were entered manually into the main database, and the macroeconomic variables automatically through the period variable for each country.

[Insert Table 1 here]

Table 1 contains the definition of the variables employed in this article. All the variables are winsorized at the $1 \%$ level to prevent any outliers in banking ratios from distorting the estimates (see Adrian et al. 2015).

\subsection{Measuring the cost of capital: The CAPM model}

The bank cost of capital is given by equity investors required rate of return. The cost of capital is approximated as in the standard CAPM model. Thus, the investors' required rate of return equals the safe gross rate of interest plus the compensation for bank $i$ 's (undiversifiable) risk, 
i.e., the product of bank $i$ 's beta multiplied by the equity market risk premium $(E R P) .{ }^{3}$ Bank cost of capital, i.e., investors' required rate of return on bank equity, at date $\mathrm{t}$ is $r_{i t}$ :

$$
r_{i t}=R_{t}^{f}+\beta_{i t} E R P_{t}
$$

As the risk-free rate $\left(R_{t}^{f}\right)$, we take the yield on the 10-year Bund (German sovereign bond), as this length of maturity approximates a typical shareholder's investment horizon.

The variable of interest is $\beta_{i t}$, known as the CAPM beta, which measures the covariance of the return of stock $i\left(R_{i}\right)$ with the return of the market portfolio $\left(R_{m}\right)$, over the variance of the market portfolio return:

$$
\beta_{i t}=\frac{\operatorname{Cov}\left(R_{i}, R_{m}\right)}{\operatorname{Var}\left(R_{m}\right)}
$$

Following the methodology used by Fama and MacBeth (1973), we estimate time-varying betas $\left(\beta_{i t}\right)$ using a 24-month rolling-window OLS regression for each bank $i$, since betas can change substantially over time. ${ }^{4} \mathrm{We}$ approximate the equity market risk premium at time $t\left(E R P_{t}\right)$ using the historical means of realized EURO STOXX returns in excess of the contemporaneous 10-year Bund yield over the past 60 months' (five years') observations, beginning in January 1990. This procedure enables us to obtain estimations from 2002 to 2016. The bank-specific equity premium at time $t$ then equals the product of its CAPM Beta and the equity market risk premium at time t, $\beta_{i t}\left(E R P_{t}\right)$.

\footnotetext{
${ }^{3}$ See King (2009) for a similar approach.

${ }^{4}$ The assumption of constant betas for 5-year periods would be justified if betas were changing as close enough to a snail's pace as is the case in diversified portfolios. Since new information is incorporated following the banking and sovereign debt crises, betas for individual stocks may change rapidly and the assumption of a 5-year window may not be applicable.
} 


\subsection{Measuring liquidity creation}

We calculate bank $i$ 's liquidity creation $\left(L C_{i t}\right)$ in thousands of Euros following the three- step method used by Berger and Bouwman (2009) and Berger et al. (2016) on US banks. The components of $L C_{i t}$ are listed in Appendix A:

$$
\begin{gathered}
L C_{i t}=0.5 \times \text { illiquid assets }+0.5 \times \text { liquid liabilities } \\
-0.5 \times \text { liquid assets }-0.5 \times \text { illiquid liabilities } \\
-0.5 \times \text { equity }
\end{gathered}
$$

The above indicator can be interpreted as the capacity of bank $i$ to transform illiquid assets into liquid assets in order to transmit liquidity to the real sector, thus improving capital allocation and promoting economic growth (Berger and Bouwman 2009; Berger et al. 2016a). Alternative LC indicator: To test the robustness of the results obtained on $L C_{i t}$, we reformulate the liquidity creation indicator $\left(L C_{i t}^{\prime}\right)$ by including the items customer depositscurrent and customer deposits-savings as 'semi-liquid liabilities', and customer deposits-term and deposits from banks as 'liquid liabilities'.

\subsection{Regression analysis}

This section discusses the strategy for identifying and estimating the long- and short-term impacts of NPLs on the cost of capital, and thereby on lending and liquidity supply. ${ }^{5}$

Our empirical strategy is based on the following autoregressive distributed lags (hereafter ADL) model broken down as follows: ${ }^{6}$

$$
r_{i t}=\alpha_{0}+\alpha_{1} r_{i t-1}+\alpha_{2} N P L_{i t}+\alpha_{3} N P L_{i, t-1}+X_{i, t-1}^{\prime} \Phi+v_{i}+u_{i t}
$$

where the variable $r_{i t}$ is bank $i$ 's cost of capital. The explanatory variables of interest are $N P L_{i t}$, which represents the non-performing loans ratio as defined in Table 1, and the lagged value of

\footnotetext{
${ }^{5}$ SeeCarbó-Valverde et al. (2017)for a similar approach.

${ }^{6}$ Note that the ADL model is equivalent to error-correction by substituting $y_{i t}=y_{i, t-1}+\Delta y_{i t}$ and $N P L_{i t}=$ $N P L_{i, t-1}+\triangle N P L_{i t}$. In the error correction mechanism, the adjustment of y towards its equilibrium is defined by the deviations of both variables lagged by one period: $y_{i, t-1}-\frac{\alpha_{2}+\alpha_{3}}{1-\alpha_{1}} N P L_{i, t-1}$.
} 
the cost of capital $\left(r_{i, t-1}\right)$ as defined in expression (1). The matrix $X_{i, t-1}^{\prime}$ is a set of control variables including the following: the bank leverage ratio $\left(L E V_{i, t-1}\right)$, which is measured as total assets over total equity and controls for shortage of bank capital; the variable $\operatorname{LOANTA}_{i, t-1 \text {, }}$ which is computed as the loans to total assets ratio and represents the level of risk that the bank

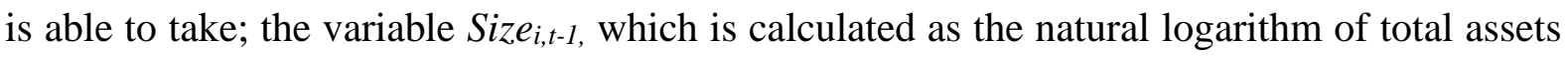
and controls for firm size; the Lerner index $\left(\right.$ Lerner $\left._{i, t-1}\right)$, which controls for the degree of competition and is calculated as the difference between the price and the marginal costs, divided by the price ${ }^{7}$; the income structure ratio $\left(I N C_{i, t-1}\right)$, which is computed as non-interest income to total assets and controls for business diversification; and the efficiency ratio $\left(E F F_{i, t-}\right.$ 1), which is calculated as operating costs over gross income. We control for the structural break after the beginning of the financial crisis by including the dummy variable Crisis, which takes the value one if $t \geq 2007 \mathrm{Q}$, and zero otherwise. Finally, we control for the effects of the sovereign debt crisis on the dependent variables by including the volume of 10-year sovereign CDS $\left(C D S_{h t}\right)$ for the home country of each bank.

With respect to the interpretation of expression (4), the ADL enables us to test whether the relationship between $N P L_{i t}$ and the indicators included in $r_{i t}$ are actually dynamic (i.e., $H_{0}: \alpha_{1}=$ $\alpha_{3}=0$ ) and to assess the contemporaneous effect, or short-term effect, (i.e., $H_{0}: \alpha_{2}=0$ ). Furthermore, if the above hypotheses are rejected, the steady-state relationship can be estimated as follows:

$$
\gamma=\frac{\alpha_{2}+\alpha_{3}}{1-\alpha_{1}} \text { if }\left|\alpha_{1}\right|<1
$$

\footnotetext{
${ }^{7}$ Marginal costs are calculated following the transcendental logarithmic costs function which includes operating (labour, capital and deposits) and financial costs, and a trend to control for technological changes over time (e.g., Fernández de Guevara et al. 2005; Carbó-Valverde et al. 2009; Carbó-Valverde et al. 2009; Cruz-García et al. 2017; Mansilla-Fernández 2020).
} 
where $\left|\alpha_{1}\right|<1$ is the necessary and sufficient condition for the existence of a globally asymptotically 'stable' solution. ${ }^{8}$ Finally, if the null $\left(H_{0}: \gamma=0\right)$ is rejected, we can confirm the presence of the above-mentioned long-term equilibrium.

The second research question is about the effects of the cost of capital on credit supply. Since the consequences of NPLs on bank balance sheets are transmitted to banking markets as a higher cost for capital, we repeat the procedure proposed earlier to assess whether the increase in the cost of capital has an impact on long- and short-term credit supply and liquidity creation. Thus, we propose the following ADL specification:

$$
\operatorname{LOANTA}_{i t}=\delta_{0}+\delta_{1} \text { LOANTA }_{i t-1}+\delta_{2} r_{i t}+\delta_{3} r_{i t-1}+X_{i, t-1}^{\prime} \Omega+v_{i}^{\prime}+u_{i t}^{\prime}
$$

All the variables and subscripts are defined above. The transmission of the cost of capital to credit supply is expected to be negative in both the short-term and the long-term (i.e., $\delta_{2}$ and $\delta_{3}<0$, and $\left.\left|\delta_{1}\right|<1\right)$.

Finally, the third research question examines whether the cost of capital has repercussions on banks' liquidity-generation capacity. Based on the above reasoning, we propose the following ADL model:

$$
\frac{L C_{i t}}{T A_{i t}}=\delta_{0}^{\prime}+\delta_{1}^{\prime}\left(\frac{L C_{i t-1}}{T A_{i t-1}}\right)+\delta_{2}^{\prime} r_{i t}+\delta_{3}^{\prime} r_{i t-1}+X_{i, t-1}^{\prime} \Lambda+v^{\prime \prime}{ }_{i}+u^{\prime \prime}{ }_{i t}
$$

where $L C_{i t}$ represents liquidity creation as defined in expression (3), and all the variables and subscripts are defined above.

\footnotetext{
${ }^{8}$ Two further solutions are possible. The unstable solution or hysteresis $(\alpha=1)$ means that the solution contains a linear trend and that the initial condition exerts full influence on $y_{i t}$. The explosive solution $(|\alpha|>1)$ is the opposite of the 'stable' solution, i.e., the effect of the regressor is divergent on $y_{i t}$.
} 


\section{Results}

\subsection{Summary statistics and parametric tests}

Table 2 displays the summary statistics of the variables employed in this study. The values in panel A confirm the absence of outliers in the sample. The results of a mean-differences test are shown in Panel B. As a first step, we create the dummy variable Crisis, which takes the value one from the beginning of the banking crisis $(t \geq 2007 Q 3)$, and zero otherwise. The alternative hypothesis is confirmed $\left(H_{1}: \operatorname{Crisis}_{t}(0)-\operatorname{Crisis}_{t}(1)<0\right)$ for the CAPM beta $\left(\beta_{i t}\right)$ and the cost of capital $\left(r_{i t}\right)$, thus indicating that banks were perceived to be riskier than before, and were therefore required to pay higher returns as the crisis set in. Simultaneously, the test reflects that banks' book profitability $\left(R O E_{i t}\right)$ was statistically lower after the crisis $\left(H_{1}: \operatorname{Crisis}_{t}(0)-\operatorname{Crisis}_{t}(1)<0\right)$, whereas the gap between the (expected) cost of capital and banks' return on book value $\left(r_{i t}-R O E_{i t}\right)$ widened after the crisis $\left(H_{1}: \operatorname{Crisis}_{t}(0)-\right.$ $\left.\operatorname{Crisis}_{t}(1)>0\right)$. Accurately, the tests also reject the null for the NPL ratio $\left(H_{1}:\right.$ Crisis $_{t}(0)-$ $\operatorname{Crisis}_{t}(1)<0$ ), thus reflecting that the volume of impaired loans was significantly higher during the crisis period. Taken into consideration that NPLs were one of the main risk sources for the Eurozone banks during our period of analysis (Accornero et al. 2017; Chiesa and Mansilla-Fernández 2018; Anastasiou et al. 2019), our results reflect that equity investors required banks to satisfy increasing returns on equity, potentially in excess of book value returns, during the crisis years.Finally, the test also rejects the null for banks' credit supply $\left(L O A N T A_{i t}\right)$, and liquidity creation $\left(L C_{i t} / T A_{i t}\right.$ and $\left.L C_{i t}^{\prime} / T A\right)$, thus confirming that banks' production figures dropped significantly after the crisis.

\section{[Insert Table 2 here]}

In the light of the previous assessment, we now look for linear trends of the CAPM Beta, the cost of capital and profitability measures as NPLs accumulate on banks' balance sheets. To 
this end, Panel $\mathrm{C}$ presents estimates of the average values and standard deviation of the key variables, breaking the sample down into quartiles of the NPL ratio $\left(N P L_{i t}\right)$. Importantly, our results show that the higher the NPL ratio, the higher the CAPM beta $\left(\beta_{i t}\right)$, thus confirming that banks accumulating impaired loans are perceived as relatively riskier than their counterparts. In line with previous results (Chiesa and Mansilla-Fernández, 2018), the cost of capital displays an increasing trend with respect to the NPL ratio, thus confirming that relatively risky banks are required to pay higher equity returns. In the same line, we also observe that the average value of the profitability gap $\left(r_{i t}-R O E_{i t}\right)$ also increases as the bank accumulates NPLs, which suggests that accumulating impaired loans might lead equity investors to require higher than book value returns.

\subsection{Assessing the European fragmentation}

It could be argued that financial fragmentation can affect the speed of capital cost adjustment. Previous literature has examined how the 2010 debt crisis and the weak balance sheets of periphery country banks reduced the supply of credit in so-called periphery countries (Bijsterbosch and Falagiarda 2015; Mayordomo et al. 2015). Importantly, recent empirical evidence reveals that both sovereign and corporate bond markets, which were well integrated prior to the crisis, substantially fragmented as investors 'flew to quality'(Zaghini 2016; Horny et al. 2018). Thus, following literature dealing with fragmentation and differences in NPL ratios between the two 'Europes' (Anastasiou et al. 2019), we consider it worth analysing whether fragmentation plays a role in our transmission channel.

[Insert Table 3 here]

To this end, we classify banks as core-country or periphery-country depending on their geographical sphere of operation. Table 3 reports the results from a parametric test for the whole period of analysis (2002Q1-2016Q4), the quarters before the crisis (2002Q1-2007Q2) 
and during the crisis (2007Q3-2016Q4), under the null that both groups of banks display similar features. Interestingly, the test fails to reject the null for the pre-crisis NPL ratio $\left(N P L_{i t}\right)$ but confirms the alternative for the crisis quarters $\left(H_{1}\right.$ : $\operatorname{Core}(0)-$ Periphery $\left.(1)<0\right)$. This confirms that deterioration in macroeconomic conditions causes a deterioration of the portfolio quality of periphery country banks with respect to their core peers. As expected, the alternative hypothesis is confirmed $\left(H_{1}\right.$ : Core $(0)-$ Periphery $\left.(1)<0\right)$ for the CAPM beta $\left(\beta_{i t}\right)$ and the cost of capital $\left(r_{i t}\right)$, which grow further apart during the crisis period. Interestingly, the test also fails to reject the null of a pre-crisis profitability gap, whereas the alternative is confirmed for the period after the onset of the crisis $\left(H_{1}\right.$ : Core $(0)-$ Periphery $\left.(1)<0\right)$, which implies that periphery country banks found it harder than those of core countries to meet profitability requirements. With respect to lending and liquidity measures, observation shows that, although periphery country banks supply relatively more credit and liquidity at any time $\left(H_{1}\right.$ : Core $(0)-$ Periphery $(1)<0$ ), the gap between the two groups of banks widens as the crisis advances. Last but not least, it emerges that core country banks are comparatively better capitalized $\left(H_{1}\right.$ : Core $(0)-$ Periphery $\left.(1)>0\right)$, this being a steering factor of credit fragmentation between the two 'Europes' (Bijsterbosch and Falagiarda 2015; Mayordomo et al. 2015; Zaghini 2016).

\subsection{Testing for unit root and cointegration analysis}

In this subsection we demonstrate the non-spuriousness of our regression results. Investigation of the long-term effects of NPLs on the cost of capital, and the subsequent impact on lending and liquidity supply, essentially requires testing for the stationarity of the time series of crosssection panel units, after which it can be determined whether the cost of capital can be cointegrated with $N P L_{i t}, L O A N T A_{i t}$, as well as $L C_{i t} / T A_{i t}$ and $L C_{i t}^{\prime} / T A_{i t}$. 


\subsubsection{Testing for unit roots}

Causality tests are highly sensitive to the stationarity of the times series dimension of the panel dataset. Thus, data stationarity is tested using the Augmented Dickey-Fuller (ADF) test for the presence of unit roots (Dickey and Fuller 1979, 1981); and Perron's (1989) ADF test to distinguish between the pre and post 2008 crisis.

$$
\Delta z_{i t}=\mu+\gamma^{*} z_{i, t-1}+\sum_{j=1}^{p-1} \vartheta_{i} \Delta z_{i, t-j}+e_{i t}
$$

Panel A of Table 4 shows the results of the ADF tests for before the financial crisis, for the period following its onset, and for the study period as a whole. The results reject the null hypothesis for unit roots at the $1 \%$ and $5 \%$ levels, which confirms that there is not nonstationary random behaviour. ${ }^{9}$

[Insert table 4 here]

\subsubsection{Testing for cointegration}

We conduct the Johansen-Fisher's panel co-integration test proposed by Maddala and $\mathrm{Wu}$ (1999) for panel data, which adds the $p$-values of the Johansen individual eigenvectors and trace statistics, thereby deriving the following statistical test:

$$
\lambda=-2 \sum_{i=1}^{N} \log \left(\pi_{i}\right) \sim \chi_{2 N}^{2}
$$

where $\pi_{i}$ is the p-value of an individual cross-section $i \ldots N$, under the null hypothesis of no cointegration for panel data.

Panel B of Table 4 displays the trace statistics and the significance level for the existence of a long-term relationship between the cost of capital $\left(r_{i t}\right)$, the NPL ratio, lending supply and liquidity creation. The test fails to reject the null hypothesis of less than two co-integrating

\footnotetext{
${ }^{9}$ This test is conducted under the null $\gamma^{*}=\left(\sum_{i=1}^{p} \gamma_{i}\right)-1=0$.
} 
vectors at any level, which confirms the cointegrating relationship between the cost of capital and the target variables of this study. ${ }^{10}$

The above-discussed results, when taken together, enable us to conclude that we are able to obtain non-spurious estimates of the contemporaneous (i.e., short-term) and steady-state (i.e., long-term) coefficients for the effects of the NPL ratio and lending and liquidity supply on the cost of capital.

\subsection{The effects of NPLs on the cost of capital}

The first research question that this paper endeavours to answer is whether the accumulation of NPLs might, in the long term, shift banks' cost of capital towards an average value, namely the steady-state relationship (H-1). The regression results of expression (4) based on the Arellano and Bond (1991) GMM estimator ${ }^{11}$ are shown in Table 5.

[Insert Table 5 here]

The estimates on the contemporaneous parameters $\left(\alpha_{2}\right)$ are positive and statistically significant, indicating that banks accumulating impaired loans are required to pay relatively higher equity market returns in the short term (see, Chiesa and Mansilla-Fernández 2018). Interestingly, we find that the coefficient results are higher for the periphery country banks than for the core country banks. These results reveal that growing NPLs might contribute to the fragmentation of equity markets because investors would require periphery country banks to provide higher compensation for non-diversifiable risk, which then translates into higher equity returns. ${ }^{12}$

\footnotetext{
${ }^{10}$ Anastasiou (2017) and Anastasiou et al. (2019) use cointegration and causality techniques, respectively, to test for persistent macroeconomic and business cycle effects on non-performing loans. This article goes further by extending the analysis to the long-term repercussions of accumulating non-performing loans on capital financing and bank functioning.

${ }^{11}$ Two-, three-, and four-period-period lagged instrumental variables are used to control for possible endogeneity issues deriving from correlations of errors over time. The Sargan test and serial autocorrelation tests of second $(A R(2))$ and third order $(A R(3))$ are performed to test for orthogonality of the instruments.

${ }^{12}$ Recall that periphery country banks accumulated relatively larger volumes of impaired loans on their balance sheets (Barba Navaretti et al. 2017; Mansilla-Fernández 2017; Climent-Serrano 2019). Consequently, according
} 
This study extends previous literature by investigating whether the cost of capital can reach a long-term equilibrium, i.e., the steady-state, following an NPL ratio shock. The estimates of the steady-state coefficients, as shown in expression (5), are positive and statistically significant, suggesting that an impact on NPLs might increase the cost of capital in the longterm. Interestingly, the cost of capital reaches a stronger steady state for the periphery country banks than for those in the core countries, thus suggesting that banks headquartered in relatively weaker economies might find it harder to issue new capital.

In Panel B of Table 6, we repeat our econometric exercise by taking into consideration the one-period-lagged credit default swaps at the country level $\left(C D S_{h t-1}\right)$ so as to capture sovereigndebt crisis effects (Reinhart and Rogoff 2010, 2011; Ehrmann and Fratzscher 2017; Horny et al. 2018). ${ }^{13}$ While the results are qualitatively similar to those discussed above, the estimates are slightly higher for the post-crisis period, which means that equity investors increase their return requirements when the risk associated with impaired loans is combined with macroeconomic uncertainty.

\subsection{The effects of the cost of capital on the supply of credit}

Having demonstrated that increases in the NPL ratio might increase the cost of capital for banks, the second research question for us to address is whether this translates into a shortage of credit supply (H-2). Panel A of Table 6 displays the regression results for the whole period of analysis (2002Q1-2016Q4).

\section{[Insert Table 6 here]}

As expected, the negative and statistically significant estimates on the contemporaneous parameter $\left(\alpha_{2}\right)$ suggest that increases in the cost of capital might reduce the supply of credit to

to the transmission channel under investigation in this study, equity investors perceive these institutions as relatively riskier than core country banks (see, Chiesa and Mansilla-Fernández 2018).

${ }^{13}$ Following Vides et al. (2018) who perform a thorough analysis of the integration of European stock markets after the sovereign-debt crisis, we include the CDS of sovereign debt at the country level to avoid confounding effects. 
customers in the short-term. Furthermore, the estimated parameters are comparatively higher for periphery country banks. These results suggest that more severe credit cuts to customers might be expected in banking systems where conditions encourage the accumulation of impaired loans. Importantly, the steady-state estimated parameters are negative and statistically significant, revealing persistent flattening of the credit supply curve over time due to increases in the cost of capital. We find this effect to be economically more significant for banks headquartered in periphery countries, where worsening macroeconomic conditions and banks' accumulations of impaired loans (Accornero et al. 2017; Barba Navaretti et al. 2017; Grigoli et al. 2018) threatened their profitability (Zhang et al. 2016) and solvency (Shi et al. 2017; Ghosh 2017; Mohaddes et al. 2017) .

The leading literature on banking regulation and stability considers capital as the cornerstone of the theory, since it determines the amounts that banks are allowed to lend (Van den Heuvel 2008; Dagher et al. 2016). Accordingly, bank undercapitalization should be seen as a crucial gear in the transmission channel to lending supply (see, Fell et al. 2017, 2018). Thus, we include the leverage ratio $\left(L E V_{i t}\right)$ as a control variable for shortage of capital. The estimates on $L E V_{i t}$ are negative and significant, confirming that the more reduced a bank's capital, the less credit it extends to customers (Bank for International Settlements 2017; Manaresi and Pierri 2018). As a novelty, this paper investigates the possibility of interaction between bank undercapitalization and the cost of capital, to which end we create the $L E V_{i t} \times r_{i t}$ and $L E V_{i t} \times r_{i t-1}$ interaction variables which control for the multiplicative effect of leverage to variations in the cost of capital $\left(r_{i t}\right)$. The negative and statistically significant signs of the interaction variables suggest that the greater a bank's leverage, the greater the negative impact of the cost of capital on its lending. That is, results indicate that shortage of bank capital exacerbates the negative effects of the cost of capital on credit provision. Interestingly, we find that multiplicative effects between leverage and cost of capital are economically more 
significant for periphery country banks, which were under-capitalized in comparison with their core country peers.

Panel B of Table 6 displays the regression results for the crisis period (2008Q1-2016Q4) and includes CDS per country as a regressor. The estimates are qualitatively similar to those discussed above. Thus, the coefficient estimates reveal that the crisis intensified both the contemporaneous and the steady-state effects of the cost of capital on lending supply. Remarkably, the results also suggest that the interaction effects intensify during the crisis periods for periphery country banks.

\subsection{The effects of the cost of capital on liquidity creation}

We now answer the third research question, which is whether banks' cost of capital reduces liquidity creation; or, in other words, diminish their capacity to function (H-3). Table 7 displays the regression results of expression (7).

\section{[Insert Table 7]}

The estimates show that the cost of capital impacts negatively on liquidity creation both in the short-term (contemporaneous effect) and in the long-term (steady-state relationship). In particular, our results suggest that banks facing a relatively higher cost of capital have less capacity to transform maturity. Unsurprisingly, our results demonstrate that periphery country banks are comparatively more sensitive to changes in liquidity creation following increases in their cost of capital.

We now investigate whether shortage of capital is a determinant of liquidity creation. The estimates on the leverage ratio $\left(L E V_{i t}\right)$ are negative and significant, suggesting that shortage of capital reduces banks' capacity to create liquidity for the real sector. Importantly, we look into the presence of multiplicative effects between the cost of capital and the leverage ratio as described in the previous sub-section. The negative and significant sign of the estimates on $L E V_{i t} \times r_{i t}$ and $L E V_{i t} \times r_{i t-1}$ reveals that shortage of capital emphasises the deleterious effects 
of the cost of capital on liquidity creation. Furthermore, this phenomenon is economically more significant for periphery country banks.

Panel B shows the qualitatively similar results obtained when isolating the effects of the sovereign debt crisis (Reinhart and Rogoff 2010, 2011). As discussed in the previous subsection, the steady-state estimated coefficients are moderately higher for the crisis sub-period. We also find that, since equity investors increase their required rate of return in times of banking and sovereign crisis, maturity transformation is reduced even further in the long-term.

Robustness test: The results from the alternative definition of liquidity creation $L C_{i t}^{\prime} / T A_{i t}$ are qualitatively similar and robust to the standard definition of liquidity creation. ${ }^{14}$

\subsection{Further robustness check: The Granger causality test}

This section examines potential causality among the variables of interest within the transmission channel (Appendix B). ${ }^{15}$ We find that the NPL ratio has explanatory power on the cost of capital, but not vice versa, thus confirming that $N P L_{i t}$ is strictly exogenous. We are also able to confirm the causality of the cost of capital over lending and liquidity supply, but find no empirical evidence for the reverse effect. Thus, the results confirm the exogeneity of the regressors, and the one-way directionality of the transmission channel, as formulated in this research. ${ }^{16}$

\section{Conclusions}

This paper analyses the contemporaneous effects and the steady-state relationship of the NPLscost of capital-lending and liquidity supply transmission channel (Chiesa and Mansilla-

\footnotetext{
${ }^{14}$ Results upon request.

15 The definition of causality, as defined by Granger (1969) and Sims (1972), states that lagged values of $y_{i t}$ should not have explanatory power on movements of $x_{i t}$ beyond that provided by lagged values of $x_{i t}$; more formally $f\left(x_{t} \mid x_{t-1}, y_{t-1}\right)=f\left(x_{t} \mid x_{t-1}\right)$. Importantly, the variable $x_{i t}$ is weakly exogenous if it has no explanatory power on any other variable in the regression. Finally, if $x_{i t}$ is weakly exogenous and if $y_{t-1}$ is non-significant, then $x_{i t}$ is strongly exogenous (see also Greene, 2012, page 358).

${ }^{16}$ We follow the methodology used by Holtz-Eakin et al. (1988) for panel data with individual fixed effects.
} 
Fernández 2018). A single database is created for this purpose by combining Bankscope accounting data (Bureau van Dijk) with market information from Thomson Reuters Datastream and macroeconomic information from Eurostat.

The main finding of this study is that not only do NPLs have repercussions on the cost of capital in the short-term (the contemporaneous effect) but that this impact also persists in the long-term (the steady-state). In line with previous studies analysing persistent effects of NPLs (Anastasiou 2017; Anastasiou et al. 2019), this article demonstrates that persistent effects of the cost of capital contribute to reducing banks' lending and liquidity capacity (e.g., Berger and Bouwman 2009; Berger et al. 2016a). This effect accelerates as banks become undercapitalized, since banking regulations require them to hold minimum ratios of regulatory capital to risk-weighted assets (Caprio and Summers 1996; Diamond and Rajan 2000; Calomiris and Jaremski 2016). To be more specific, the transmission mechanism that concerns us is economically more significant for banks headquartered in the so-called periphery countries (see Chiesa and Mansilla-Fernández 2018).

Finally, the results are robust to endogeneity tests and the Granger causality tests, thus confirming the one-way directionality of the transmission channel under investigation. 
Figure 1. Evolution and box-plot representation of the non-performing loans ratio and the cost of capital of periphery country and core country banks, before (2002Q1-2007Q2) and after (2007Q3-2016Q4) the crisis.

(a) Evolution of the NPL ratio

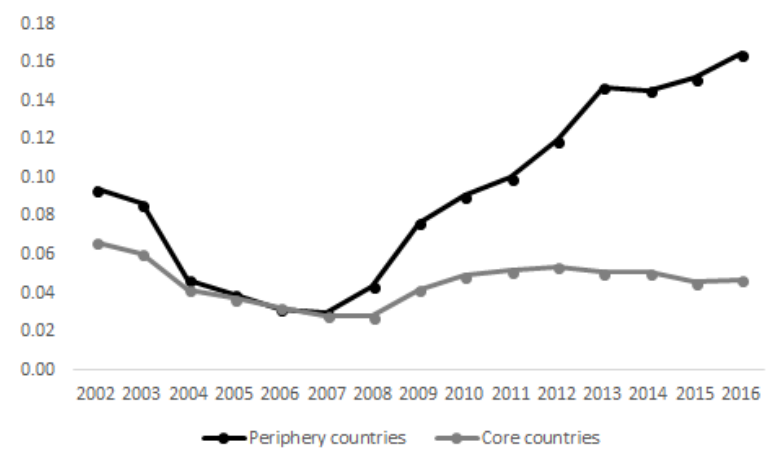

(c) Evolution of the NPL ratio

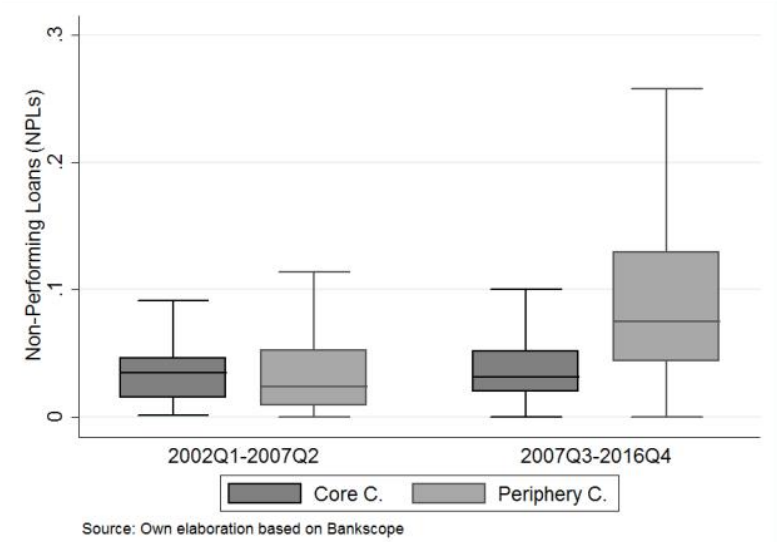

(b) Evolution of the Beta $\operatorname{CAPM}\left(\beta_{i t}\right)$

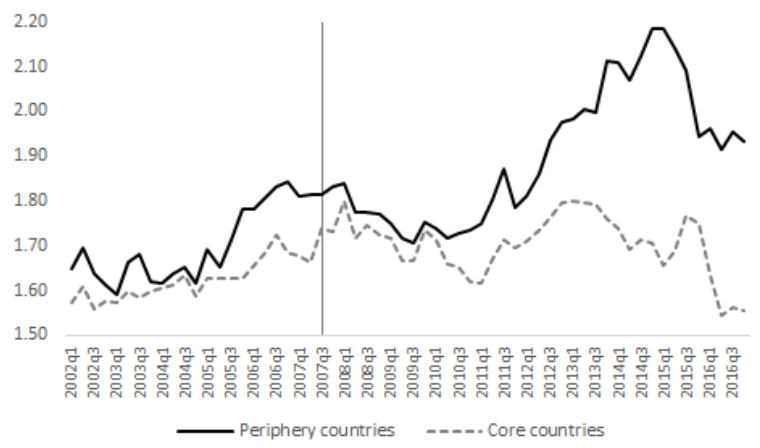

(d) Box plot of the Beta $\operatorname{CAPM}\left(\beta_{i t}\right)$

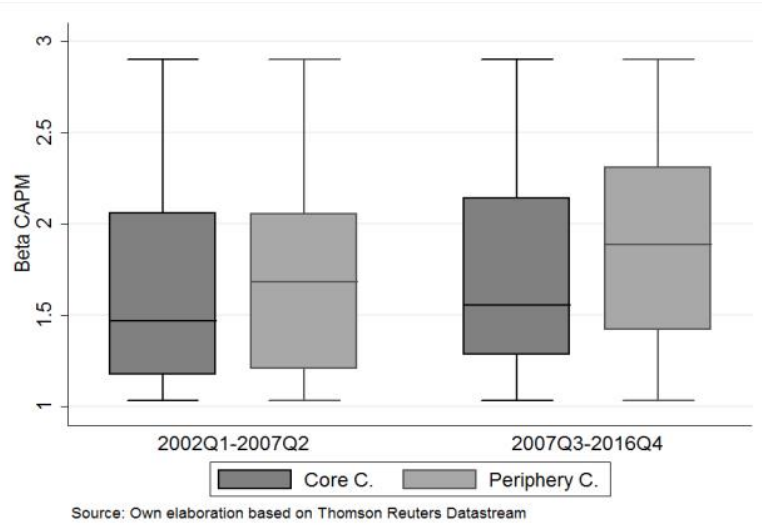

Source: Authors' estimation based on Bankscope and Thomson Reuters Datastream. The solid line represents the periphery countries, and the dashed line, the periphery countries. The vertical line splits the sample into the pre- and post crisis subperiods $(t=2007 \mathrm{Q} 2)$. Subfigure (a) displays the evolution of the non-performing loans ratio $\left(N P L_{i t}\right)$ with the sample broken down first by sub-periods, and then by core and periphery countries. Subfigure (b) displays the evolution of the cost of capital $\left(r_{i t}\right)$ by sample sub-periods, and by core and periphery countries. Subfigure (c) displays the distribution of NPL $L_{i t}$ by sub-periods, and by core and periphery countries. Subfigure (d) displays the distribution of the Beta CAPM $\left(\beta_{i t}\right)$ by sub-periods, and by core and periphery countries. The whiskers represent the maximum and the minimum of the distribution. The box is divided into two parts by the median, i.e., the $50^{\text {th }}$ percentile of the distribution. The upper (lower) box represents the 25 percent of the sample above (below) the median, i.e., the upper (lower) quartile. 
Table 1: Variable definition

\begin{tabular}{|c|c|c|c|}
\hline Variable & Acronym & Definition & Source \\
\hline \multicolumn{4}{|l|}{ Bank variables } \\
\hline Banks' Beta-CAPM & $\beta_{i t}$ & $\begin{array}{l}\text { This variable measures the sensitivity of a bank's expected excess asset returns to the } \\
\text { expected excess market returns. This coefficient represents bank's risk taking. }\end{array}$ & $\begin{array}{l}\text { Authors' calculation based on Thomson } \\
\text { Reuters Datastream. }\end{array}$ \\
\hline $\begin{array}{l}\text { Non-performing } \\
\text { loans ratio }\end{array}$ & $N P L_{i t}$ & This variable is measured as the ratio of impaired to total loans. & Bankscope \\
\hline Return on equity & $R O E_{i t}$ & $\begin{array}{l}\text { This variable controls for bank performance. The ratio is measured as operating profits } \\
\text { (loss) over total equity. }\end{array}$ & Bankscope \\
\hline Cost of capital & $r_{i t}$ & $\begin{array}{l}\text { This variable measures investors' required return on a bank's equity. This indicator is } \\
\text { computed as } r_{i t}=E\left[R_{i t}\right]=R_{t}^{f}+\beta_{i t}\left(E\left[R_{t}^{m}\right]-R_{t}^{f}\right)=R_{t}^{f}+\beta_{i t} E R P_{t} \text {. }\end{array}$ & $\begin{array}{l}\text { Author's calculation based on Bankscope } \\
\text { and Thomson Reuters Datastream. }\end{array}$ \\
\hline Profitability gap & $r_{i t^{-}} R O E_{i t}$ & $\begin{array}{l}\text { This variable measures the difference between investors' required return andthat which the } \\
\text { bank is able to generate. }\end{array}$ & $\begin{array}{l}\text { Author's calculation based on Bankscope } \\
\text { and Thomson Reuters Datastream. }\end{array}$ \\
\hline Bank size & Size $_{i t}$ & Natural logarithm of one-period lagged total assets. & Bankscope \\
\hline Customer loans & $\operatorname{LOANTA}_{i t}$ & $\begin{array}{l}\text { This ratio measures the bank's business volume. It is measured as customer loans over total } \\
\text { assets. }\end{array}$ & Bankscope \\
\hline Liquidity creation & $L C_{i t} / T A_{i t}$ & $L C_{i t}=0.5 \times$ (illiquid assets + liquid liabilities - liquid assets - illiquid liabilities - equity $)$ & Bankscope \\
\hline Leverage & $L E V_{i t}$ & $\begin{array}{l}\text { This ratio controls for bank's solvency. This variable is constructed as the ratio of bank total } \\
\text { assets to total equity. }\end{array}$ & Bankscope \\
\hline $\begin{array}{l}\text { Degree of } \\
\text { competition }\end{array}$ & Lerner $_{i t}$ & $\begin{array}{l}\text { This index is defined as the ratio of the difference of prices and marginal costs over the } \\
\text { price. This variable measures the capacity of the bank to set a price above the marginal } \\
\text { costs. }\end{array}$ & Bankscope \\
\hline Income structure & $I N C_{i t}$ & $\begin{array}{l}\text { This ratio is measured as non-interest income over total net income. This variable controls } \\
\text { for business diversification. }\end{array}$ & Bankscope \\
\hline Efficiency & $E F F_{i t}$ & This ratio is measured as operating costs over gross income. & Bankscope \\
\hline \multicolumn{4}{|c|}{ Macroeconomic variables } \\
\hline Crisis dummy & Crisis $_{t}$ & Dummy variable which takes the value one from 2007Q3 onwards, and zero otherwise. & Eurostat \\
\hline Sovereign credit risk & $C D S_{h t}$ & This variable is) 10 -year sovereign Credit Default Swaps (CDS) at the country level $(h)$. & Thomson Reuters Datastream \\
\hline GDP growth & $G D P_{h t}$ & This variable is measured as the variation rate of GDP at the country level $(h)$ & Eurostat \\
\hline Unemployment rate & $U N E M P_{h t}$ & This variable is measured as the unemployment rate at the country level $(h)$. & Eurostat \\
\hline
\end{tabular}

Notes: subscripts $i, h$, and $t$ refer to bank, country and time, respectively. 
Table 2. Descriptive statistics

This table reports the distribution of the variables used in this research between 2002Q1 and 2016Q4. CDS values are available from 2008Q1 to 2016Q4. Panel A shows the descriptive statistics of the sample. Panel B displays mean values and standard errors for the same variables for the years before (2002Q1 - 2007Q2) and after (2007Q3 - 2016Q4) the crisis. The parametric tests estimate the differences in mean values under the null $\mathrm{H}_{0}$ : Crisis $(0)-$ Crisis $_{t}(1)=0$, where Crisis $_{t}=1$ if $t \geq 2007 \mathrm{Q}$, and zero, otherwise. Panel $\mathrm{C}$ displays the summary statistics of the main variables employed in this study by quartiles of the non-performing loans ratio $\left(N P L_{i t}\right)$ for the whole sample. The regression coefficients represent the mean variable, whilst the standard errors are represented in parentheses. All specifications are estimated using OLS. The F-statistics are shown to test the differences in the dependent variables across the quartiles of $N P L_{i t}$, and the $p$-value is represented in brackets. Estimates followed by $*, * *, * * *$ are statistically significant at $10 \%, 5 \%$, and $1 \%$, respectively. The sample includes commercial banks, savings banks, and credit unions operating in the Euro area countries. The bank variables are winsorized at the 1 percent level to remove outliers. All the variables are defined in Table 1.

PANEL A: Description of the sample

\begin{tabular}{|c|c|c|c|c|c|c|c|c|}
\hline & $\mathbf{N}$ & Mean & SD & Min. & Pc. 25 & Median & Pc. 75 & Max. \\
\hline \multicolumn{9}{|c|}{ Bank variables } \\
\hline$\beta_{i t}$ & 2,400 & 1.7658 & 0.5490 & 1.0312 & 1.2797 & 1.6806 & 2.1804 & 2.8976 \\
\hline$E R P_{t}$ & 2,400 & 0.0710 & 0.0303 & 0.0333 & 0.0409 & 0.0647 & 0.1064 & 0.1239 \\
\hline$r_{i t}$ & 2,400 & 0.1609 & 0.0657 & 0.0802 & 0.1067 & 0.1467 & 0.2010 & 0.3078 \\
\hline$r_{i t^{-}} R O E_{i t}$ & 2,400 & 0.1236 & 0.1663 & 0.0001 & 0.0075 & 0.1047 & 0.1996 & 0.5528 \\
\hline$N P L_{i t}$ & 2,400 & 0.0875 & 0.0846 & 0.0063 & 0.0343 & 0.0607 & 0.1136 & 0.4785 \\
\hline Size $_{i t}$ & 2,400 & 24.2487 & 2.1571 & 18.5862 & 22.7461 & 24.0957 & 25.8649 & 28.2834 \\
\hline$R O E_{i t}$ & 2,400 & 0.0588 & 0.1308 & -0.3235 & 0.0250 & 0.0787 & 0.1268 & 0.2609 \\
\hline LOANTA $_{i t}$ & 2,400 & 0.5964 & 0.2028 & 0.0552 & 0.5340 & 0.6357 & 0.7477 & 0.8781 \\
\hline$L C_{i t} / T A_{i t}$ & 2,400 & 0.3180 & 0.2765 & -0.4631 & 0.1243 & 0.3299 & 0.5172 & 1.0236 \\
\hline$L C^{\prime}{ }_{i t} / T A_{i t}$ & 2,400 & 0.2132 & 0.1911 & -0.4242 & 0.1024 & 0.2358 & 0.3323 & 0.7347 \\
\hline$L E V_{i t}$ & 2,400 & 16.3633 & 7.8301 & 4.3577 & 11.0884 & 14.8399 & 19.1339 & 46.5409 \\
\hline Lerner $_{i t}$ & 2,400 & 0.1020 & 0.0333 & 0.0784 & 0.0784 & 0.1020 & 0.1255 & 0.1255 \\
\hline$I N C_{i t}$ & 2,400 & 0.3625 & 0.2257 & 0.0000 & 0.2250 & 0.3084 & 0.4256 & 1.1734 \\
\hline$E F F_{i t}$ & 2,400 & 0.3044 & 0.1364 & 0.1020 & 0.2152 & 0.2700 & 0.3514 & 0.8571 \\
\hline \multicolumn{9}{|c|}{ Macro economic variables } \\
\hline Crisis $_{t}$ & 2,400 & 0.6333 & 0.4820 & 0.0000 & 0.0000 & 1.0000 & 1.0000 & 1.0000 \\
\hline$C D S_{i t}$ & 1,251 & 124.7894 & 140.9011 & 10.3333 & 46.0500 & 76.5000 & 145.6400 & 1190.6200 \\
\hline$G D P_{h t}$ & 2,460 & 0.0131 & 0.0271 & -0.0983 & 0.0030 & 0.0136 & 0.0269 & 0.2760 \\
\hline$U N E M P_{h t}$ & 2,400 & 8.9772 & 4.4502 & 3.1333 & 5.7333 & 8.3000 & 10.2333 & 26.2000 \\
\hline
\end{tabular}


PANEL B: Parametric test for comparison of means before (2002Q1 - 2007Q2) and after (2007Q3 - 2016Q4) the crisis $\left(\mathrm{H}_{0}\right.$ : Crisis $(0)-$ Crisis $\left._{t}(1)=0\right)$. Standard errors in parentheses.

\begin{tabular}{|c|c|c|c|}
\hline & 2002Q1 - 2007Q2 & 2007Q3 - 2016Q4 & $\begin{array}{c}\text { t-test } \\
{[p \text {-value }]}\end{array}$ \\
\hline \multirow[t]{2}{*}{$\beta_{i t}$} & 1.6653 & 1.8182 & -8.3959 \\
\hline & $(0.0138)$ & $(0.0109)$ & {$[0.0000]$} \\
\hline \multirow[t]{2}{*}{$r_{i t}$} & 0.1170 & 0.1837 & -34.6443 \\
\hline & $(0.0009)$ & $(0.0013)$ & {$[0.0000]$} \\
\hline \multirow[t]{2}{*}{$r_{i t}-R O E_{i t}$} & 0.0877 & 0.1924 & -5.3886 \\
\hline & $(0.0109)$ & $(0.0041)$ & {$[0.0000]$} \\
\hline \multirow[t]{2}{*}{$N P L_{i t}$} & 0.0465 & 0.0937 & -5.2897 \\
\hline & $(0.0043)$ & $(0.0034)$ & {$[0.0000]$} \\
\hline \multirow[t]{2}{*}{ Size $_{i t}$} & 24.0591 & 24.2878 & -1.4132 \\
\hline & $(0.1422)$ & $(0.0673)$ & {$[0.0789]$} \\
\hline \multirow[t]{2}{*}{$R O E_{i t}$} & 0.1243 & 0.0465 & 18.1944 \\
\hline & $(0.0029)$ & $(0.0018)$ & {$[0.0000]$} \\
\hline \multirow[t]{2}{*}{$L_{O A N T A_{i t}}$} & 0.5660 & 0.6026 & -2.4042 \\
\hline & $(0.0116)$ & $(0.0068)$ & {$[0.0082]$} \\
\hline \multirow[t]{2}{*}{$L C_{i t} / T A_{i t}$} & 0.2785 & 0.3024 & -2.8234 \\
\hline & $(0.0074)$ & $(0.0036)$ & {$[0.0024]$} \\
\hline \multirow[t]{2}{*}{$L C^{\prime}{ }_{i t} / T A_{i t}$} & 0.2234 & 0.2111 & 2.1478 \\
\hline & $(0.0054)$ & $(0.0023)$ & [0.0159] \\
\hline \multirow[t]{2}{*}{$L E V_{i t}$} & 17.8797 & 16.0513 & 3.1218 \\
\hline & $(0.4686)$ & $(0.2475)$ & [0.0009] \\
\hline
\end{tabular}

PANEL C: Means of the key variables depending on the quartiles of $N P L_{i t}$.

\begin{tabular}{|c|c|c|c|c|c|}
\hline & 1st Quartile & 2nd Quartile & 3rd Quartile & 4th Quartile & $\begin{array}{c}\text { F-test } \\
{[p \text {-value }]}\end{array}$ \\
\hline \multirow[t]{2}{*}{$\beta_{i t}$} & $1.8142^{* * *}$ & $1.8334^{* * *}$ & $1.9696^{* * *}$ & $2.2221^{* * * *}$ & $5,754.41$ \\
\hline & $(0.0275)$ & $(0.0262)$ & $(0.0242)$ & $(0.0261)$ & {$[0.0000]$} \\
\hline \multirow[t]{2}{*}{$r_{i t}$} & $0.1528^{* * *}$ & $0.1754^{* * *}$ & $0.2077^{* * *}$ & $0.2113^{* * *}$ & $3,053.36$ \\
\hline & $(0.0036)$ & $(0.0034)$ & $(0.0032)$ & $(0.0034)$ & {$[0.0000]$} \\
\hline \multirow[t]{2}{*}{$r_{i t}-R O E_{i t}$} & $0.1290^{* * *}$ & $0.1407^{* * *}$ & $0.1904^{* * *}$ & $0.2755^{* * *}$ & 521.95 \\
\hline & $(0.0092)$ & $(0.0113)$ & $(0.0079)$ & $(0.0081)$ & {$[0.0000]$} \\
\hline \multirow[t]{2}{*}{ Size $_{i t}$} & $24.540^{* * *}$ & $25.512^{* * *}$ & $25.070^{* * * *}$ & $24.786^{* * * *}$ & $38,949.65$ \\
\hline & $(0.127)$ & $(0.127)$ & $(0.127)$ & $(0.127)$ & {$[0.0000]$} \\
\hline \multirow[t]{2}{*}{$R O E_{i t}$} & $0.1132^{* * *}$ & $0.0912^{* * *}$ & $0.0560^{* * *}$ & $-0.0387^{* * *}$ & 456.61 \\
\hline & $(0.0037)$ & $(0.0037)$ & $(0.0038)$ & $(0.0038)$ & {$[0.0000]$} \\
\hline
\end{tabular}


Table 3. Parametric tests for the comparison of means for core and periphery countries, before and after the crisis.

This table breaks the sample down between banks in the periphery countries (Cyprus, Greece, Ireland, Italy, Latvia, Lithuania, Portugal, Slovakia, Spain) and in the core countries (Austria, Belgium, Estonia, Finland, France, Germany, Luxembourg, Malta, Slovenia, and The Netherlands). The parametric tests are performed under the null $\mathrm{H}_{0}$ : Core (0) - Periphery (1) $=0$ for the following periods: (i) the whole period (2002Q1 - 2016Q4), (ii) before the crisis (2002Q1 2007Q2), and (iii) after the crisis (2007Q3 - 2016Q4). All the variables are defined in Table 1. The coefficients represent mean values, whereas standard errors are in parentheses. The t-statistics is reported for each test, and the $p$-value is shown in brackets.

\begin{tabular}{|c|c|c|c|c|c|c|c|c|c|}
\hline & \multicolumn{3}{|c|}{ 2002Q1 - 2016Q4 } & \multicolumn{3}{|c|}{$2002 Q 1-2007 Q 2$} & \multicolumn{3}{|c|}{ 2007Q3-2016Q4 } \\
\hline & Core & Periphery & $\begin{array}{c}\text { t-test } \\
{[p \text {-value }]}\end{array}$ & Core & Periphery & $\begin{array}{c}\text { t-test } \\
{[p \text {-value }]}\end{array}$ & Core & Periphery & $\begin{array}{c}\text { t-test } \\
{[p \text {-value }]}\end{array}$ \\
\hline \multirow[t]{2}{*}{$\beta_{i t}$} & 1.6770 & 1.8296 & -8.7096 & 1.6243 & 1.6942 & -2.4850 & 1.7041 & 1.9012 & -8.9922 \\
\hline & $(0.0127)$ & $(0.0117)$ & {$[0.0000]$} & $(0.0217)$ & $(0.0179)$ & [0.0065] & $(0.0156)$ & $(0.0148)$ & [0.0000] \\
\hline \multirow[t]{2}{*}{$r_{i t}$} & 0.1550 & 0.1650 & -4.7107 & 0.1145 & 0.1187 & -2.2761 & 0.1759 & 0.1894 & -5.1488 \\
\hline & $(0.0015)$ & $(0.0014)$ & {$[0.0000]$} & $(0.0014)$ & $(0.0012)$ & [0.0115] & $(0.0019)$ & $(0.0017)$ & [0.0000] \\
\hline \multirow[t]{2}{*}{$r_{i t^{-}} R O E_{i t}$} & 0.1412 & 0.2100 & -8.1650 & 0.0738 & 0.1117 & -1.6861 & 0.1427 & 0.2158 & -8.4328 \\
\hline & $(0.0049)$ & $(0.0053)$ & [0.0000] & (0.0107) & $(0.0231)$ & [0.0963] & $(0.0050)$ & $(0.0054)$ & [0.0000] \\
\hline \multirow[t]{2}{*}{$N P L_{i t}$} & 0.0386 & 0.1018 & -9.0369 & 0.0568 & 0.0444 & 1.0806 & 0.0366 & 0.1114 & -9.9275 \\
\hline & $(0.0018)$ & $(0.0037)$ & {$[0.0000]$} & $(0.0086)$ & $(0.0049)$ & [0.2825] & $(0.0018)$ & $(0.0041)$ & [0.0000] \\
\hline \multirow[t]{2}{*}{ Size $_{i t}$} & 23.7881 & 24.4791 & -5.4071 & 23.9616 & 24.0927 & -0.4018 & 23.7618 & 24.5698 & -5.8098 \\
\hline & $(0.1262)$ & $(0.0646)$ & {$[0.0000]$} & $(0.3405)$ & $(0.1516)$ & [0.6882] & $(0.1361)$ & $(0.0711)$ & [0.0000] \\
\hline \multirow[t]{2}{*}{$R O E_{i t}$} & 0.0761 & 0.0445 & 9.8814 & 0.1120 & 0.1345 & -3.7650 & 0.0693 & 0.0276 & 11.8953 \\
\hline & $(0.0019)$ & $(0.0024)$ & {$[0.0000]$} & $(0.0045)$ & $(0.0039)$ & [0.0002] & $(0.0021)$ & $(0.0027)$ & {$[0.0000]$} \\
\hline \multirow[t]{2}{*}{$L O A N T A_{i t}$} & 0.4868 & 0.6510 & -14.5876 & 0.4634 & 0.6017 & -5.5477 & 0.4903 & 0.6625 & -13.7765 \\
\hline & $(0.0135)$ & $(0.0042)$ & {$[0.0000]$} & $(0.0314)$ & $(0.0098)$ & [0.0000] & $(0.0148)$ & $(0.0045)$ & [0.0000] \\
\hline \multirow[t]{2}{*}{$L C_{i t} / T A_{i t}$} & 0.3279 & 0.2663 & 9.6727 & 0.3211 & 0.2219 & 6.7324 & 0.3296 & 0.2744 & 7.8057 \\
\hline & $(0.0042)$ & $(0.0048)$ & {$[0.0000]$} & $(0.0086)$ & $(0.0125)$ & [0.0000] & $(0.0048)$ & $(0.0052)$ & [0.0000] \\
\hline \multirow[t]{2}{*}{$L C^{\prime}{ }_{i t} / T A_{i t}$} & 0.2400 & 0.1843 & 12.9074 & 0.2616 & 0.1727 & 8.2823 & 0.2349 & 0.1865 & 10.2838 \\
\hline & $(0.0029)$ & $(0.0031)$ & [0.0000] & $(0.0067)$ & $(0.0085)$ & [0.0000] & $(0.0033)$ & $(0.0033)$ & [0.0000] \\
\hline \multirow[t]{2}{*}{$L E V_{i t}$} & 17.3101 & 15.8899 & 3.0375 & 20.9633 & 16.8130 & 4.0042 & 16.7565 & 15.6731 & 2.0895 \\
\hline & $(0.5207)$ & $(0.2038)$ & [0.0012] & (1.4619) & $(0.3432)$ & [0.0000] & $(0.5523)$ & $(0.2377)$ & [0.0185] \\
\hline \multirow[t]{2}{*}{$C D S_{h t}$} & - & - & - & - & - & - & 66.3132 & 154.9519 & -11.7934 \\
\hline & & & & & & & $(2.3452)$ & (5.9483) & [0.0000] \\
\hline
\end{tabular}


Table 4: Unit root and cointegration analysis with structural break

This table presents the results of the tests for unit root and cointegration. Panel A displays the Augmented Dickey-Fuller test for the key variables employed in this study. The coefficients represent the impact on the one-period-lagged coefficient of the dependent variable, whilst the standard errors are shown in parentheses. Panel B shows the results of the Johansen-Fisher's panel cointegration test for the endogenous variables of this study. Endogenous variables include the cost of capital $\left(r_{i t}\right)$, NPLs ratio $\left(N P L_{i t}\right)$, credit supply $\left(L O A N T A_{i t}\right)$, liquidity creation $\left(L C_{i t} / T A_{i t}\right)$, and modified liquidity creation $\left(L C^{\prime}{ }_{i t}\right.$ $\left./ T A_{i t}\right)$. Trace (statistical $t$ ) is reported for the years before (2002Q1 - 2007Q2) and after (2007Q3 2016Q4) the crisis. All the variables are defined in Table 1. Estimates followed by *,**,*** represent the rejection of the null hypothesis of unit roots at 10,5 , and $1 \%$, respectively; whilst estimates followed by,,++++++ indicate cointegration at 10,5 , and $1 \%$ respectively.

PANEl A: Augmented Dickey-Fuller test with four lags

\begin{tabular}{|c|c|c|c|c|c|c|}
\hline & \multicolumn{2}{|c|}{ 2002Q1-2007Q2 } & \multicolumn{2}{|c|}{ 2007Q3-2016Q4 } & \multicolumn{2}{|c|}{ 2002Q1-2016Q4 } \\
\hline & Coefficient $\left(\theta_{1}\right)$ & t-stats & Coefficient $\left(\theta_{1}\right)$ & t-stats & Coefficient $\left(\theta_{1}\right)$ & t-stats \\
\hline$r_{i t}$ & $\begin{array}{c}-0.4807^{* * * *} \\
(0.0266)\end{array}$ & -18.71 & $\begin{array}{c}-0.4584^{* * * *} \\
(0.0214)\end{array}$ & -21.42 & $\begin{array}{c}-0.4556^{* * * *} \\
(0.0286)\end{array}$ & -15.93 \\
\hline$N P L_{i t}$ & $\begin{array}{c}-0.6033^{* * *} \\
(0.2655)\end{array}$ & -2.27 & $\begin{array}{l}-0.6034^{* *} \\
(0.2655)\end{array}$ & -2.27 & $\begin{array}{l}-0.6034^{* *} \\
(0.2665)\end{array}$ & -2.27 \\
\hline$L_{O A N T A_{i t}}$ & $\begin{array}{c}-0.8937^{* * * *} \\
(0.0680)\end{array}$ & -13.13 & $\begin{array}{c}-0.8433^{* * * *} \\
(0.0498)\end{array}$ & -16.91 & $\begin{array}{c}-0.6922^{* * * *} \\
(0.1672)\end{array}$ & -4.14 \\
\hline$L C_{i} / T A_{i t}$ & $\begin{array}{c}-0.8099^{* * * *} \\
(0.1888)\end{array}$ & -4.29 & $\begin{array}{l}-0.7064^{* *} \\
(0.1979)\end{array}$ & -3.57 & $\begin{array}{c}-0.7197^{* * * *} \\
(0.0737)\end{array}$ & -9.76 \\
\hline$L C^{\prime}{ }_{i t} / T A_{i t}$ & $\begin{array}{c}-0.7875^{* * * *} \\
(0.1090)\end{array}$ & -7.22 & $\begin{array}{l}-0.6467^{* * *} \\
(0.2567)\end{array}$ & -2.52 & $\begin{array}{c}-0.7938^{* * * *} \\
(0.0759)\end{array}$ & -10.45 \\
\hline
\end{tabular}

PANEL B: Johansen-Fisher's panel cointegration test. Endogenous variable: $r_{i t}$

\begin{tabular}{ccccc}
\hline \hline \multicolumn{2}{c}{$\mathrm{H}_{0}$ : Range $=\mathrm{r}$} & $\mathbf{2 0 0 2 Q 1 - 2 0 0 7 Q 2}$ & & $\mathbf{2 0 0 7 Q 3 - 2 0 1 6 Q 4}$ \\
${$\cline { 1 - 2 }$} }$ & $\mathrm{r}=0$ & $106.0438^{+++}$ & & $338.4015^{+++}$ \\
& $\mathrm{r} \leq 1$ & $42.1169^{+++}$ & & $100.0807^{+++}$ \\
LOANTA $_{i t}$ & $\mathrm{r}=0$ & $184.7151^{+++}$ & & $768.1435^{+++}$ \\
& $\mathrm{r} \leq 1$ & $65.0611^{+++}$ & & $163.8656^{+++}$ \\
\multirow{2}{*}{$L C_{i t} / T A_{i t}$} & $\mathrm{r}=0$ & $116.3871^{+++}$ & & $497.4280^{+++}$ \\
& $\mathrm{r} \leq 1$ & $56.3515^{+++}$ & & $92.7950^{+++}$ \\
$L C^{\prime}{ }_{i t} / T A_{i t}$ & $\mathrm{r}=0$ & $124.6141^{+++}$ & & $488.7806^{+++}$ \\
& $\mathrm{r} \leq 1$ & $52.5215^{+++}$ & & $90.1121^{+++}$ \\
\hline
\end{tabular}


Table 5. The effects of non-performing loans on bank's cost of capital $\left(r_{i t}\right)$.

This table provides the regression results of the effects of the non-performing loans ratio $\left(N P L_{i t}\right)$ on bank's cost of capital. Quarterly observations for Eurozone listed banks are applied for all the specifications. Panel A includes the regression analysis the whole sample. Panel B includes the regression results for the post-crisis period. The dependent variable is the cost of capital $\left(r_{i t}\right)$. The variables Crisis $s_{i t}$ controls for the structural break, and it is a dummy variable which takes the value one after the beginning of the crisis $(t \geq 2007 \mathrm{Q} 3)$, and zero, otherwise. Values for CDS are available from 2008Q1 to 2016Q4. All the specifications are estimated using the Arellano and Bond's (1991) GMM. The set of instruments includes $t-2, t-3$, and $t-4$ lagged variables. Economic growth $\left(G D P_{h t}\right)$ and unemployment rate $\left(U N E M P_{h t}\right)$ are included as exogenous variables. Instruments validity is tested using a Sargan test of overidentifying restrictions and serial correlation tests ( $p$-values). The steady-state denotes the long-term effect between the dependent variable and the NPL ratio. All the variables are defined in Table1. Columns (1) and (4) display the regression values for all the countries, columns (2) and (5) for the periphery countries, and columns (3) and (6) for the core countries. Standard errors are in parenthesis and clustered at the bank level. Estimated followed by $* * *, * * *$ are statistically significant at the 10,5 and $1 \%$ level, respectively.

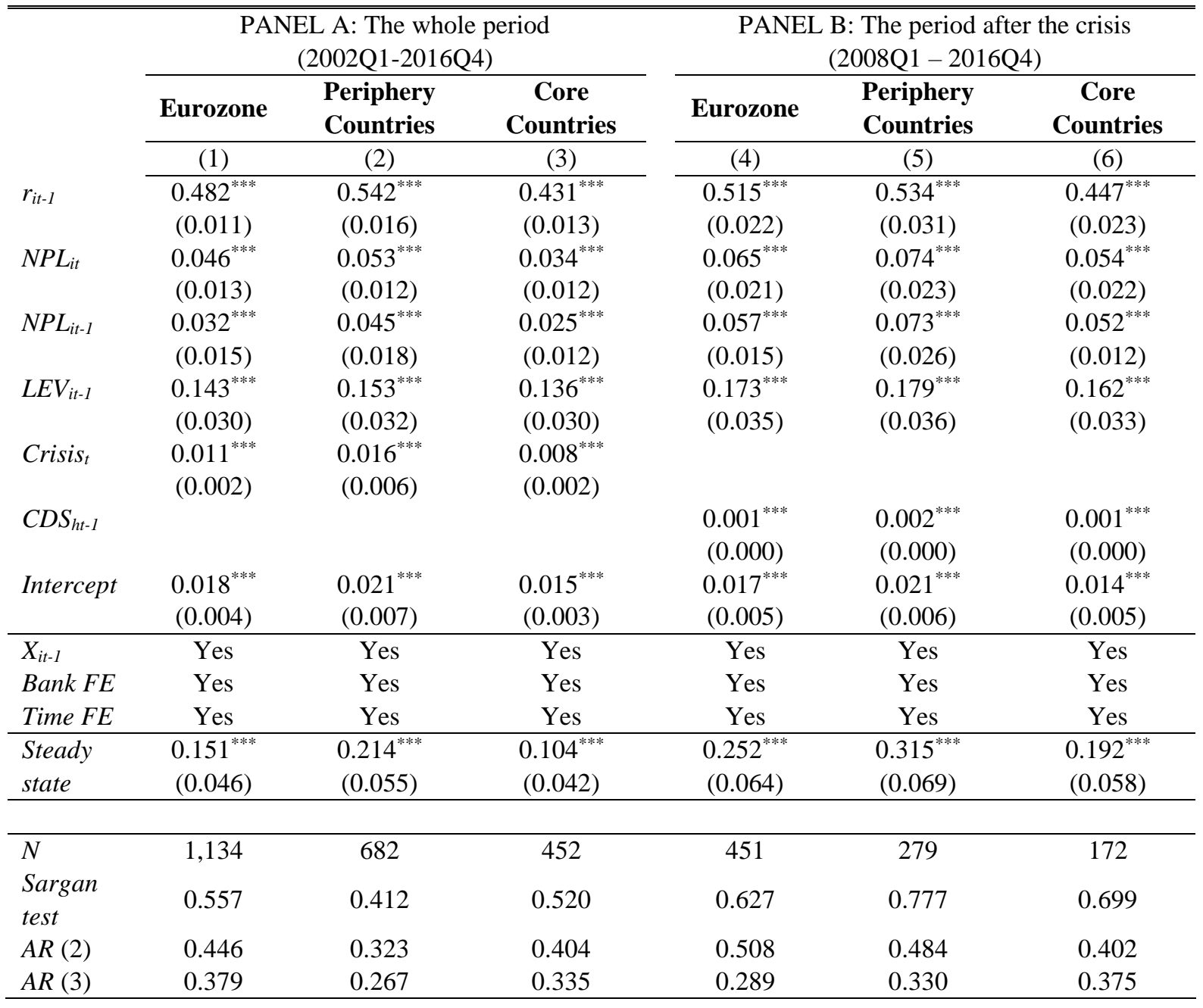


Table 6. The effects of the cost of capital $\left(r_{i t}\right)$ on the supply of credit $\left(L O A N T A_{i t}\right)$

This table provides the regression results of the effects of the cost of capital $\left(r_{i t}\right)$ on credit supply. Quarterly observations for Eurozone listed banks are applied for all the specifications. The dependent variable is the ratio of loans to customers to total assets $\left(L O A N T A_{i t}\right)$. Panel A includes the regression analysis the whole sample. Panel B includes the regression results for the post-crisis period. The variable Crisis $i$, which controls for the structural break, is a dummy variable which takes the value one after the beginning of the crisis $(t \geq 2007 \mathrm{Q} 3)$, and zero, otherwise. CDS values are available from 2008Q1 to 2016Q4. All the specifications are estimated using Arellano and Bond's (1991) GMM. The set of instruments include $t-2, t-3$, and $t-4$ lagged variables. Economic growth $\left(G D P_{h t}\right)$ and the unemployment rate $\left(U N E M P_{h t}\right)$ are included as exogenous variables. Instrument validity is tested using the Sargan test of overidentifying restrictions and serial correlation tests ( $p$-values). The steady-state denotes the long-term effect between the cost of capital and $L O A N T A_{i t}$. All the variables are defined in Table 1. Columns (1) and (4) display the regression values for the whole sample, columns (2) and (5) for the periphery countries, and columns (3) and (6) for the core countries. Standard errors are shown in parentheses and clustered at the bank level. Estimated followed by $*, * *, * * *$ are statistically significant at the 10,5 and $1 \%$ level, respectively.

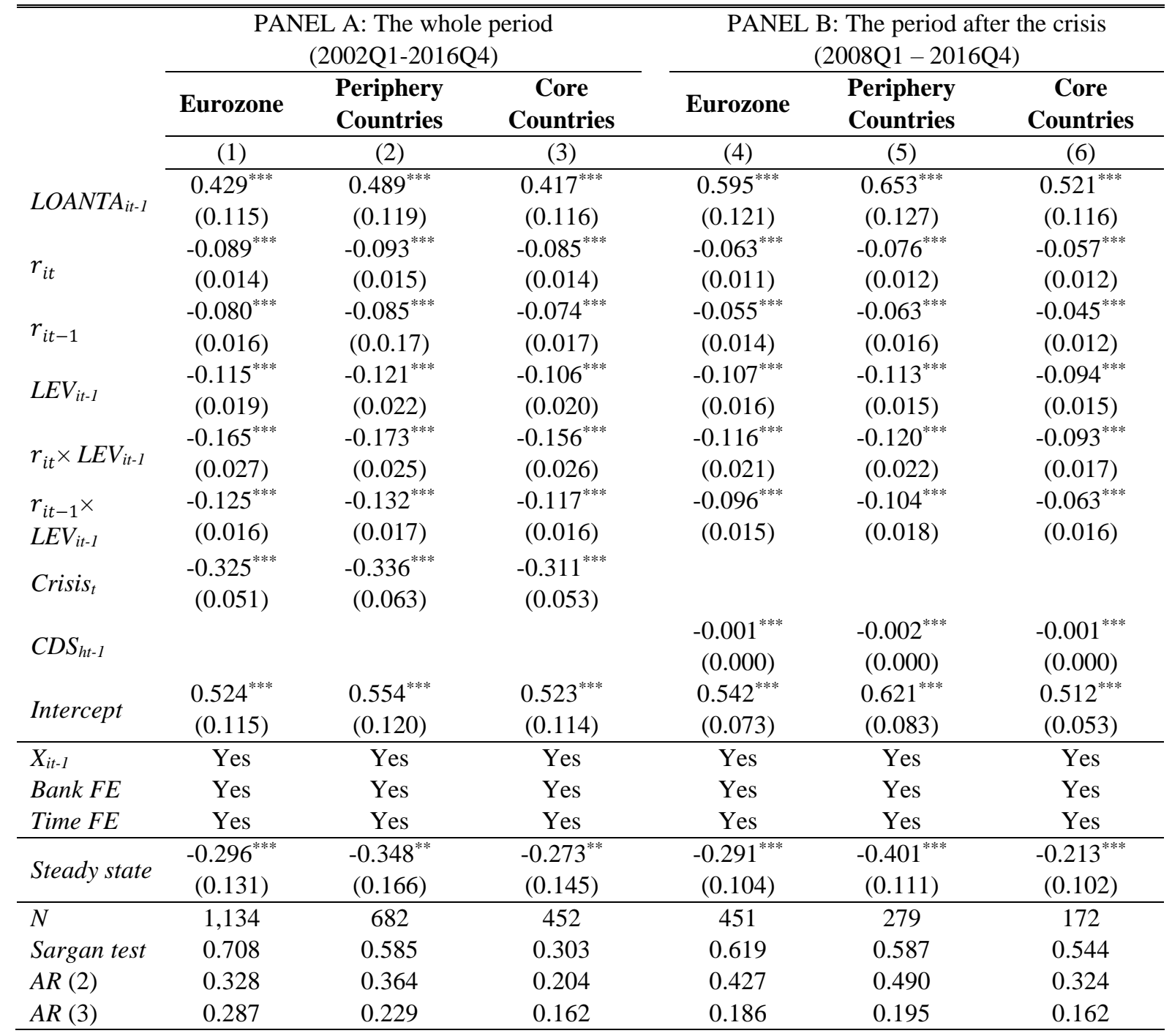


Table 7. The effects of the cost of capital $\left(r_{i t}\right)$ on liquidity creation $\left(L C_{i} / T A_{i t}\right)$

This table provides the regression results of the effects of the cost of capital $\left(r_{i t}\right)$ on liquidity creation. Quarterly observations for Eurozone listed banks are applied for all the specifications. The dependent variable is the ratio of liquidity creation to total assets $\left(L C / T A_{i t}\right)$. Panel A reports the regression analysis for the whole sample. Panel

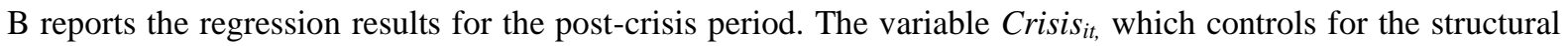
break, is a dummy variable which takes the value one after the beginning of the crisis $(t \geq 2007 \mathrm{Q} 3)$, and zero, otherwise. CDS values are available from 2008Q1 to 2016Q4. All the specifications are estimated using Arellano and Bond's (1991) GMM. The set of instruments include $t-2, t-3$, and $t-4$ lagged variables. Economic growth $\left(G D P_{h t}\right)$ and the unemployment rate $\left(U N E M P_{h t}\right)$ are included as exogenous variables. Instrument validity is tested using the Sargan test of overidentifying restrictions and serial correlation tests ( $p$-values). The steady-state denotes the long-term effect between the cost of capital and $L C / T A_{i t}$. All the variables are defined in Table 1. Columns (1) and (4) display the regression values for the whole sample, columns (2) and (5) for the periphery countries, and columns (3) and (6) for the core countries. Standard errors are shown in parentheses and clustered at the bank level. Estimated followed by $* * *, * * *$ are statistically significant at the 10,5 and $1 \%$ level, respectively.

\begin{tabular}{|c|c|c|c|c|c|c|}
\hline & \multicolumn{3}{|c|}{$\begin{array}{l}\text { PANEL A: The whole period } \\
\text { (2002Q1-2016Q4) }\end{array}$} & \multicolumn{3}{|c|}{$\begin{array}{l}\text { PANEL B: The period after the crisis } \\
\text { (2008Q1 - 2016Q4) }\end{array}$} \\
\hline & Eurozone & $\begin{array}{l}\text { Periphery } \\
\text { Countries }\end{array}$ & $\begin{array}{c}\text { Core } \\
\text { Countries }\end{array}$ & Eurozone & $\begin{array}{l}\text { Periphery } \\
\text { Countries }\end{array}$ & $\begin{array}{c}\text { Core } \\
\text { Countries } \\
\end{array}$ \\
\hline & (1) & (2) & (3) & (4) & (5) & (6) \\
\hline$(L C / T A)_{\mathrm{it}-}$ & $\begin{array}{l}0.512^{* * * *} \\
(0.124)\end{array}$ & $\begin{array}{l}0.643^{* * * *} \\
(0.127)\end{array}$ & $\begin{array}{l}0.442^{* * *} \\
(0.116)\end{array}$ & $\begin{array}{c}0.561^{* * *} \\
(0.173)\end{array}$ & $\begin{array}{c}0.681^{* * * *} \\
(0.183)\end{array}$ & $\begin{array}{l}0.432^{* * * *} \\
(0.162)\end{array}$ \\
\hline$r_{i t}$ & $\begin{array}{c}-0.134^{* * *} \\
(0.023)\end{array}$ & $\begin{array}{c}-0.163^{* * *} \\
(0.032)\end{array}$ & $\begin{array}{c}-0.118^{* * *} \\
(0.023)\end{array}$ & $\begin{array}{c}-0.127^{* * *} \\
(0.023)\end{array}$ & $\begin{array}{c}-0.153^{* * *} \\
(0.022)\end{array}$ & $\begin{array}{c}-0.103^{* * *} \\
(0.021)\end{array}$ \\
\hline$r_{i t-1}$ & $\begin{array}{c}-0.119^{* * *} \\
(0.034)\end{array}$ & $\begin{array}{c}-0.125^{* * *} \\
(0.037)\end{array}$ & $\begin{array}{c}-0.106^{* * *} \\
(0.035)\end{array}$ & $\begin{array}{c}-0.084^{* * * *} \\
(0.023)\end{array}$ & $\begin{array}{l}-0.119^{* * *} \\
(0.027)\end{array}$ & $\begin{array}{l}-0.084^{* *} \\
(0.027)\end{array}$ \\
\hline$L E V_{i t-1}$ & $\begin{array}{c}-0.074^{* * *} \\
(0.022)\end{array}$ & $\begin{array}{c}-0.081^{* * *} \\
(0.024)\end{array}$ & $\begin{array}{c}-0.064^{* * * *} \\
(0.021)\end{array}$ & $\begin{array}{c}-0.073^{* * *} \\
(0.021)\end{array}$ & $\begin{array}{c}-0.085^{* * *} \\
(0.023)\end{array}$ & $\begin{array}{c}-0.062^{* * *} \\
(0.021)\end{array}$ \\
\hline$r_{i t} \times L E V_{i t-}$ & $\begin{array}{c}-0.214^{* * *} \\
(0.061)\end{array}$ & $\begin{array}{l}-0.283^{* * *} \\
(0.064)\end{array}$ & $\begin{array}{c}-0.181^{* * *} \\
(0.058)\end{array}$ & $\begin{array}{c}-0.225^{* * *} \\
(0.042)\end{array}$ & $\begin{array}{c}-0.284^{* * *} \\
(0.046)\end{array}$ & $\begin{array}{c}-0.195^{* * *} \\
(0.043)\end{array}$ \\
\hline $\begin{array}{l}r_{i t-1} \times \\
L E V_{i t-1}\end{array}$ & $\begin{array}{c}-0.123^{* * *} \\
(0.053)\end{array}$ & $\begin{array}{l}-0.142^{* * *} \\
(0.055)\end{array}$ & $\begin{array}{c}-0.114^{* * *} \\
(0.043)\end{array}$ & $\begin{array}{c}-0.143^{* * *} \\
(0.021)\end{array}$ & $\begin{array}{c}-0.164^{* * *} \\
(0.027)\end{array}$ & $\begin{array}{c}-0.126^{* * *} \\
(0.021)\end{array}$ \\
\hline Crisis $_{t}$ & $\begin{array}{c}-0.037^{* * * *} \\
(0.006)\end{array}$ & $\begin{array}{c}-0.046^{* * * *} \\
(0.009)\end{array}$ & $\begin{array}{c}-0.032^{* * * *} \\
(0.005)\end{array}$ & & & \\
\hline$C D S_{h t-1}$ & & & & $\begin{array}{c}-0.001^{* * * *} \\
(0.000)\end{array}$ & $\begin{array}{c}-0.002^{* * *} \\
(0.000)\end{array}$ & $\begin{array}{c}-0.001^{* * *} \\
(0.000)\end{array}$ \\
\hline Intercept & $\begin{array}{l}0.253^{* * * *} \\
(0.061)\end{array}$ & $\begin{array}{c}0.325^{* * * *} \\
(0.068)\end{array}$ & $\begin{array}{c}0.231^{\text {**** }} \\
(0.061)\end{array}$ & $\begin{array}{c}0.252^{* * * *} \\
(0.043)\end{array}$ & $\begin{array}{c}0.221^{* * *} \\
(0.048)\end{array}$ & $\begin{array}{c}0.269^{* * * *} \\
(0.042)\end{array}$ \\
\hline$X_{i t-1}$ & Yes & Yes & Yes & Yes & Yes & Yes \\
\hline Bank FE & Yes & Yes & Yes & Yes & Yes & Yes \\
\hline Time FE & Yes & Yes & Yes & Yes & Yes & Yes \\
\hline $\begin{array}{l}\text { Steady } \\
\text { state }\end{array}$ & $\begin{array}{c}-0.518^{* * * *} \\
(0.248)\end{array}$ & $\begin{array}{c}-0.807^{* * * *} \\
(0.365)\end{array}$ & $\begin{array}{c}-0.401^{* * * *} \\
(0.243)\end{array}$ & $\begin{array}{c}-0.481^{* * * *} \\
(0.164)\end{array}$ & $\begin{array}{c}-0.853^{* * * *} \\
(0.238)\end{array}$ & $\begin{array}{c}-0.329^{* * * *} \\
(0.129)\end{array}$ \\
\hline$N$ & 1,134 & 682 & 452 & 451 & 279 & 172 \\
\hline $\begin{array}{l}\text { Sargan } \\
\text { test }\end{array}$ & 0.422 & 0.452 & 0.509 & 0.676 & 0.565 & 0.508 \\
\hline$A R(2)$ & 0.266 & 0.379 & 0.361 & 0.361 & 0.404 & 0.340 \\
\hline$A R(3)$ & 0.232 & 0.280 & 0.285 & 0.231 & 0.269 & 0.284 \\
\hline
\end{tabular}




\section{References}

Accornero M, Alessandri P, Carpinelli L, Sorrentino AM (2017) Non-performing loans and the supply of bank credit: evidence from Italy

Adrian T, Friedman E, Muir T (2015) The Cost of Capital of the Financial Sector

Afonso G, Kovner A, Schoar A (2011) Stressed, Not Frozen: The Federal Funds Market in the Financial Crisis. J Finance 66:1109-1139. https://doi.org/10.1111/j.1540-6261.2011.01670.x

Anastasiou D (2017) Is ex-post credit risk affected by the cycles? The case of Italian banks. Res Int Bus Financ 42:242-248. https://doi.org/https://doi.org/10.1016/j.ribaf.2017.07.051

Anastasiou D, Louri H, Tsionas M (2019) Nonperforming loans in the euro area: Are core-periphery banking markets fragmented? Int J Financ Econ 24:97-112. https://doi.org/10.1002/ijfe.1651

Arellano M, Bond S (1991) Some Tests of Specification for Panel Data: Monte Carlo Evidence and an Application to Employment Equations. Rev Econ Stud 58:277-297. https://doi.org/10.2307/2297968

Balgova M, Nies M, Plekhanov A (2016) The economic impact of reducing non-performing loans

Bank for International Settlements (2017) Basel III: Finalising post-crisis reforms

Barba Navaretti G, Calzolari G, Pozzolo AF (2017) Getting Rid of NPLs in Europe. Eur Econ Banks, Regul Real Sect 2017.1:11-30

Barnes ML, Lopez JA (2006) Alternative measures of the Federal Reserve Banks' cost of equity capital. J Bank Financ 30:1687-1711. https://doi.org/https://doi.org/10.1016/j.jbankfin.2005.09.005

Bending T, Berndt M, Betz F, et al (2014) Unlocking lending in Europe. Luxembourg

Berger AN, Bouwman CH (2009) Bank Liquidity Creation. Rev Financ Stud 22:3779-3837. https://doi.org/10.1093/rfs/hhn104

Berger AN, Bouwman CHS, Kick T, Schaeck K (2016a) Bank liquidity creation following regulatory interventions and capital support. J Financ Intermediation 26:115-141. https://doi.org/http://dx.doi.org/10.1016/j.jfi.2016.01.001

Berger AN, DeYoung R (1997) Problem loans and cost efficiency in commercial banks. J Bank Financ 21:849-870. https://doi.org/https://doi.org/10.1016/S0378-4266(97)00003-4

Berger AN, Imbierowicz B, Rauch C (2016b) The Roles of Corporate Governance in Bank Failures during the Recent Financial Crisis. J Money, Credit Bank 48:729-770. https://doi.org/10.1111/jmcb.12316

Bijsterbosch M, Falagiarda M (2015) The macroeconomic impact of financial fragmentation in the euro area: Which role for credit supply? J Int Money Financ 54:93-115. https://doi.org/https://doi.org/10.1016/j.jimonfin.2015.02.013

Bogdanova B, Fender I, Takáts E (2018) The ABCs of bank PBRs: What drives bank price-to-book ratios? BIS Q Rev March:81-95

Bruner, Robert F., Eades KM, Harris RS, Higgins RC (9AD) Best practices in estimating the cost of capital: survey and synthesis. Financ Pract Educ 13-28

Calomiris CW, Jaremski M (2016) Deposit Insurance: Theories and Facts. Annu Rev Financ Econ 8:97-120. https://doi.org/10.1146/annurev-financial-111914-041923

Caprio G, Summers LH (1996) Finance and its Reform: Beyond Laissez-Faire BT - Stability in the 
Financial System. In: Papadimitriou DB (ed). Palgrave Macmillan UK, London, pp 400-421

Carbó-Valverde S, Mansilla-Fernández JM, Rodríguez-Fernández F (2017) The effects of bank market power in short-term and long-term firm credit availability and investment. Rev Esp Financ y Contab 46:. https://doi.org/10.1080/02102412.2016.1242239

Carbó-Valverde S, Rodríguez-Fernández F, Udell GF (2009) Bank Market Power and SME Financing Constraints*. Rev Financ 13:309-340. https://doi.org/10.1093/rof/rfp003

Chiesa G, Mansilla-Fernández JM (2018) Disentangling the transmission channel NPLs-cost of capital-lending supply. Appl Econ Lett 1-6. https://doi.org/10.1080/13504851.2018.1558335

Climent-Serrano S (2019) Effects of economic variables on NPLs depending on the economic cycle. Empir Econ 56:325-340. https://doi.org/10.1007/s00181-017-1362-y

Cruz-García P, de Guevara JF, Maudos J (2017) The evolution of market power in European banking. Financ Res Lett 23:257-262. https://doi.org/https://doi.org/10.1016/j.frl.2017.06.012

Dagher J, Dell'Ariccia G, Laeven L, et al (2016) Benefits and costs of bank capital. Washington D. C.

Diamond DW, Rajan RG (2000) A Theory of Bank Capital. J Finance 55:2431-2465. https://doi.org/10.1111/0022-1082.00296

Dickey DA, Fuller WA (1979) Distribution of the Estimators for Autoregressive Time Series with a Unit Root. J Am Stat Assoc 74:427-431. https://doi.org/10.1080/01621459.1979.10482531

Dickey DA, Fuller WA (1981) Likelihood Ratio Statistics for Autoregressive Time Series with a Unit Root. Econometrica 49:1057-1072. https://doi.org/10.2307/1912517

Dimitrios A, Helen L, Mike T (2016) Determinants of non-performing loans: Evidence from Euroarea countries. Financ Res Lett 18:116-119. https://doi.org/https://doi.org/10.1016/j.frl.2016.04.008

Ehrmann M, Fratzscher M (2017) Euro area government bonds - Fragmentation and contagion during the sovereign debt crisis. J Int Money Financ 70:26-44. https://doi.org/https://doi.org/10.1016/j.jimonfin.2016.08.005

Fama EF, MacBeth JD (1973) Risk, Return, and Equilibrium: Empirical Tests. J Polit Econ 81:607636

Fell J, Grodzicki M, Metzler J, O’Brien E (2018) Non-performing loans and euro area bank lending behaviour after the crisis. Financ Stab Rev 35:9-28

Fell J, Grodzicki M, Metzler J, O’Brien E (2017) A Role for systemic asset management companies in solving Europe's non-performing loan problems. Eur Econ - Banks, Regul Real Sect 2017.1:7185

Fernandez de Guevara J, Maudos J, Pérez F (2005) Market Power in European Banking Sectors. J Financ Serv Res 27:109-137. https://doi.org/10.1007/s10693-005-6665-z

Ghosh A (2017) Sector-specific analysis of non-performing loans in the US banking system and their macroeconomic impact. J Econ Bus 93:29-45. https://doi.org/10.1016/J.JECONBUS.2017.06.002

Graham JR, Harvey CR (2001) The theory and practice of corporate finance: evidence from the field. J financ econ 60:187-243. https://doi.org/https://doi.org/10.1016/S0304-405X(01)00044-7

Granger CWJ (1969) Investigating Causal Relations by Econometric Models and Cross-spectral Methods. Econometrica 37:424-438. https://doi.org/10.2307/1912791

Greene WH (2012) Econometric Analysis: International Edition. Pearson Education Limited, Harlow, United Kingdom, UNITED KINGDOM 
Grigoli F, Mansilla M, Saldías M (2018) Macro-financial linkages and heterogeneous non-performing loans projections: An application to Ecuador. J Bank Financ 97:130-141.

https://doi.org/10.1016/J.JBANKFIN.2018.09.023

Holtz-Eakin D, Newey W, Rosen HS (1988) Estimating Vector Autoregressions with Panel Data. Econometrica 56:1371-1395. https://doi.org/10.2307/1913103

Horny G, Manganelli S, Mojon B (2018) Measuring Financial Fragmentation in the Euro Area Corporate Bond Market. J. Risk Financ. Manag. 11

King MR (2009) The cost of equity for global banks: a CAPM perspective from 1990 to 2009. BIS Q Rev September:59-73

Louzis DP, Vouldis AT, Metaxas VL (2012) Macroeconomic and bank-specific determinants of nonperforming loans in Greece: A comparative study of mortgage, business and consumer loan portfolios. J Bank Financ 36:1012-1027.

https://doi.org/https://doi.org/10.1016/j.jbankfin.2011.10.012

Maccario A, Sironi A, Zazzara C (2002) Is Banks' Cost of Equity Capital Different Across Countries? Evidence from the G10 Countries Major Banks. Rome

Maddala GS, Wu S (1999) A Comparative Study of Unit Root Tests with Panel Data and a New Simple Test. Oxf Bull Econ Stat 61:631-652. https://doi.org/10.1111/1468-0084.0610s1631

Manaresi F, Pierri N (2018) Credit supply and productivity growth

Mansilla-Fernández JM (2020) Non-performing loans, financial stability, and banking competition: Evidence for listed and non-listed Eurozone banks. Hacienda Pública Española / Rev Public Econ Forthcomin:

Mansilla-Fernández JM (2017) Numbers. Eur Econ - Banks, Regul Real Sect 2017.1:31-38

Mayordomo S, Abascal M, Alonso T, Rodriguez-Moreno M (2015) Fragmentation in the European interbank market: Measures, determinants, and policy solutions. J Financ Stab 16:1-12. https://doi.org/https://doi.org/10.1016/j.jfs.2014.11.001

Mohaddes K, Raissi M, Weber A (2017) Can Italy grow out of its NPL overhang? A panel threshold analysis. Econ Lett 159:185-189. https://doi.org/10.1016/J.ECONLET.2017.08.001

Perron P (1989) The Great Crash, the Oil Price Shock, and the Unit Root Hypothesis. Econometrica 57:1361-1401. https://doi.org/10.2307/1913712

Pinto I, Ng Picoto W (2018) Earnings and capital management in European banks - Combining a multivariate regression with a qualitative comparative analysis. J Bus Res 89:258-264. https://doi.org/https://doi.org/10.1016/j.jbusres.2017.12.034

Reinhart CM, Rogoff KS (2011) From Financial Crash to Debt Crisis. Am Econ Rev 101:1676-1706. https://doi.org/10.1257/aer.101.5.1676

Reinhart CM, Rogoff KS (2010) Growth in a Time of Debt. Am Econ Rev 100:573-578. https://doi.org/10.1257/aer.100.2.573

Shi L, Sheng P, Vochozka M (2017) The reduction cost of nonperforming loan: evidence from China's commercial bank. Appl Econ Lett 24:456-459. https://doi.org/10.1080/13504851.2016.1203052

Sims CA (1972) Money, Income, and Causality. Am Econ Rev 62:540-552

Van den Heuvel SJ (2008) The welfare cost of bank capital requirements. J Monet Econ 55:298-320. https://doi.org/https://doi.org/10.1016/j.jmoneco.2007.12.001

Vides JC, Golpe AA, Iglesias J (2018) How did the Sovereign debt crisis affect the Euro financial 
integration? A fractional cointegration approach. Empirica 45:685-706.

https://doi.org/10.1007/s10663-017-9386-2

Zaghini A (2016) Fragmentation and heterogeneity in the euro-area corporate bond market: Back to normal? J Financ Stab 23:51-61. https://doi.org/https://doi.org/10.1016/j.jfs.2016.01.009

Zhang D, Cai J, Dickinson DG, Kutan AM (2016) Non-performing loans, moral hazard and regulation of the Chinese commercial banking system. J Bank Financ 63:48-60.

https://doi.org/10.1016/J.JBANKFIN.2015.11.010

Zimmer SA, McCauley RN (1991) Bank Cost of Capital and International Competition. FRBNY Q Rev Winter (15:33-59 
APPENDIX A: Liquidity classification of bank activities

\begin{tabular}{|c|c|c|}
\hline \multicolumn{3}{|c|}{ Assets } \\
\hline Illiquid assets (weight $=1 / 2$ ) & Semiliquid assets (weight $=0$ ) & Liquid assets (weight $=-1 / 2$ ) \\
\hline Corporate commercial loans & Residential mortgage loans & Cash and due from banks \\
\hline Investment in properties & Other mortgage loans & Trading securities and at FV through income \\
\hline Foreclosed real estate & Other consumer / retail loans & Tradable derivatives \\
\hline Fixed assets & Loans and advances to banks & Available for sale securities \\
\hline Goodwill & Reverse repos and cash collateral & Held to maturity securities \\
\hline Other intangibles & & At-equity investment in associates \\
\hline Other assets & & Other securities \\
\hline \multicolumn{3}{|c|}{ Liabilities } \\
\hline Liquid liabilities $($ weight $=1 / 2$ ) & Semiliquid liabilities (weight $=0$ ) & Illiquid liabilities (weight $=-1 / 2$ ) \\
\hline Customer deposits-current & Customer deposits-term & Senior debt maturing after 1 year \\
\hline Customer deposits-savings & Deposits from banks & Subordinated borrowing \\
\hline Tradable derivatives & Repos and cash collateral & Other funding \\
\hline Trading liabilities & Other deposits and short-term borrowing & Credit impairment reserves \\
\hline & Fair value proportion of debt & Reserves for pensions and others \\
\hline & & Current tax liabilities \\
\hline & & Deferred tax liabilities \\
\hline & & Other deferred liabilities \\
\hline & & Other liabilities \\
\hline \multicolumn{3}{|c|}{ Off-balance-sheet activities } \\
\hline Illiquid activities (weight $=1 / 2)$ & Semiliquid activities (weight $=0$ ) & Liquid activities (weight $=-1 / 2$ ) \\
\hline $\begin{array}{l}\text { Acceptances and documentary credits reported } \\
\text { Committed credit lines }\end{array}$ & $\begin{array}{l}\text { Managed securitized assets reported off-balance } \\
\text { sheet }\end{array}$ & \\
\hline Other contingent liabilities & $\begin{array}{l}\text { Other off-balance-sheet exposure to securitizations } \\
\text { Guarantees }\end{array}$ & \\
\hline \multicolumn{3}{|c|}{ Equity } \\
\hline & & Total equity (weight $=-1 / 2$ ) \\
\hline & & Equity \\
\hline
\end{tabular}

Notes: We follow Berger and Bowman (2009) to classify the on- and off- balance sheet items according to their liquidity status. See also Fu et al. (2006) for a similar approach. All the variables are obtained from Bureau van DijkBankscope. 


\section{APPENDIX B. GRANGER CAUSALITY TEST}

We use the Granger causality test to assess the direction of the causality between NPLs and our variables of study: the cost of capital, CAPM beta, ROE and the gap between the cost of capital and ROE. We employ four lags $(l)$ of the variables in order to capture the long-term effects of NPLs on the target variables. Since we are using panel data, we follow the Holtz-Eaking et al.'s (1988) methodology with individual fixed effects $\left(f_{i}\right)$. The statistical significance of the test is measured by using an $F$-test.

In order to test whether NPLs predict our variables of study, two conditions should be meet:

i) The NPLs ratio $\left(N P L_{i t}\right)$ should be statistically significant to the cost of capital $\left(r_{i t}\right)$ :

$$
r_{i t}=\varphi_{0}+\sum_{l=1}^{L} \varphi_{l} r_{i, t-l}+\sum_{l=1}^{L} \psi_{l} N P L_{i, t-l}+v_{t}+f_{i}+\varepsilon_{i t}
$$

ii) The cost of capital $\left(r_{i t}\right)$ should not be significant in explaining NPLs (NPLit):

$$
N P L_{i t}=\varphi_{0}^{\prime}+\sum_{l=1}^{L} \varphi_{l}^{\prime} r_{i, t-l}+\sum_{l=1}^{L} \psi_{l}^{\prime} N P L_{i, t-l}+v_{t}+f_{i}+\varepsilon_{i t}^{\prime}
$$

